\title{
Children's Time Use Changes During Periods of Financial Hardship
}

\author{
Jessica L. Arnup ${ }^{1 \dagger}$, Nicole Black ${ }^{1}$, David W. Johnston ${ }^{1}$
}

${ }^{\dagger}$ Corresponding author, E: Jessica.arnup1@monash.edu. M: (+61)418133986

${ }^{1}$ Centre for Health Economics, Monash Business School, Monash University, 900 Dandenong Road, Caulfield East, VIC 3145 Australia.

Conflicts of interest/Competing interests: The authors have no conflict of interest

Availability of data and material: This paper uses unit record data from Growing Up in Australia, the Longitudinal Study of Australian Children (LSAC). LSAC is conducted by the Australian Government Department of Social Services (DSS). The findings and views reported in this paper, however, are those of the authors and should not be attributed to the Australian Government, DSS or any of DSS' contractors or partners.

Funding: Jessica Arnup is supported through an Australian Government Research Training Program (RTP) Scholarship. Nicole Black is supported by an Australian Research Council fellowship (DE180100438).

Data Availability: The datasets analyzed during the current study are available, subject to application, via the Longitudinal Study of Australian Children Dataverse, https://dataverse.ada.edu.au/dataverse/lsac 


\begin{abstract}
Economically disadvantaged children are more likely to experience poor cognitive, health, and behavioral outcomes than other children. The mechanisms for these associations are not fully understood, hindering policy initiatives aimed at closing the gaps. One hypothesis is that children experiencing financial hardship allocate their time differently. In this study, we use seven waves of time use diary data from a large sample of Australian children to explore how children's time use changes when their family experiences financial hardship or deprivation. Focusing on four key child health and development time inputs-screen time, physical activity, sleep, and reading - we find that financial hardship is associated with significantly more screen time, particularly passive screen time and screen time at excessive levels. Potential mechanisms for these associations are explored.
\end{abstract}

Keywords: time use, screen time, financial hardship, material deprivation, poverty JEL: D1, I1, I3 


\section{Introduction}

Reducing social and economic inequalities in child health and development outcomes is of considerable importance. However, the precise mechanisms through which disadvantage impacts child outcomes is not fully understood, making it difficult to develop effective policies and programs. One under-researched hypothesis we explore in this study is that children experiencing financial hardship allocate their time differently. In particular, we seek to explore whether, during times of family financial hardship, children spend more time engaging in activities that are less cognitively enriching and less healthy.

Research has shown that child time use is an important input for cognitive and non-cognitive development (Adelantado-Renau et al., 2019; Borga, 2019; Caetano, Kinsler, \& Teng, 2019; Del Boca, Monfardini, \& Nicoletti, 2017; Fiorini \& Keane, 2014; Nguyen et al., 2020; Price \& Kalil, 2019; Subrahmanyam, Kraut, Greenfield, \& Gross, 2000). For example, Fiorini and Keane (2014) show that among children aged zero to eight years old, educational activities, particularly with parents, is the most productive input for their cognitive skill development. How children spend their time also matters for the production of health, with recent research paying particular attention to the relationship between time inputs (such as watching TV and playing sports) and childhood obesity (Cappuccio et al., 2008; Cawley \& Liu, 2012; Fertig, Glomm, \& Tchernis, 2009; LeBlanc et al., 2015). The importance of children's time inputs for health is also stressed by the World Health Organization (2019) guidelines, which recommend how much time children should spend being physically active, sleeping, and watching screens.

While there is evidence of a socioeconomic gradient in the amount of time and type of activities that parents engage in with their children (Bianchi \& Robinson, 1997; Guryan, Hurst, \& Kearney, 2008; Haveman \& Wolfe, 1995; Kalil, Ryan, \& Corey, 2012), there is limited research on how children's own time use is impacted by family socioeconomic disadvantage. In this study, we explore how children's time use changes when their family experiences serious financial (or material) hardship, such as not being able to pay bills, going without meals, and being unable to heat or cool the home. Such evidence is important for furthering our understanding of the possible pathways through which socioeconomic disadvantage relates to poorer child outcomes. It can also help target policies that can reduce the negative impacts of financial hardship on children.

Our measure of financial hardship, which is referred to as material hardship in some literatures, measures the inability to consume basic goods and services as a consequence of not having 
enough money. While financial hardship is closely related to, and can overlap with, poverty or low income (Iceland \& Bauman, 2007), they are distinct concepts (Short, 2005). Income alone does not capture information about a household's level of wealth or debt, nor their ability to meet basic expenses. We focus on financial hardship because it is often more informative about a family's material deprivation and living conditions (Iceland \& Bauman, 2007), in particular, those that may be important for children's development (Clark, D'Ambrosio, \& Barazzetta, 2021; Gershoff, Aber, Raver, \& Lennon, 2007; McCulloch \& Joshi, 2002; Schenck-Fontaine \& Panico, 2019; Zilanawala \& Pilkauskas, 2012). ${ }^{1}$ Furthermore, our data show that the average health and developmental outcomes are considerably worse for children who are experiencing financial hardship compared with more traditional measures of poverty or disadvantage (see Appendix Table A1).

Financial hardship may impact children's time use in several ways. First, families facing financial difficulties must make choices about how to allocate their limited resources, including money and time (Haveman \& Wolfe, 1995). Financial hardship may make it difficult for families to afford cognitively stimulating resources (e.g. books, puzzles), extracurricular activities (e.g. sports, music, academic lessons), or outings (e.g. library, museum, concerts) for their child (Gershoff et al., 2007). This may lead to a substitution away from costly or parent-involved activities toward more affordable, yet potentially less enriching activities, such as watching screens.

Second, financial deprivation can be cognitively demanding on parents, which can lead them to focus more on immediate concerns, often at the expense of longer term investments (Mani, Mullainathan, Shafir, \& Zhao, 2013; Shah, Mullainathan, \& Shafir, 2012). Economically disadvantaged parents may find their attention consumed by pressing household matters, leaving them fewer attentional resources to spend on making optimal parenting decisions (Mullainathan \& Shafir, 2013) and adequate parental monitoring (Cobb-Clark, Salamanca, \& Zhu, 2019). For example, they may be more inconsistent in parenting or may be less likely to actively monitor how much time their children are spending on screens or doing homework.

Third, psychology and sociology literatures suggest that financial stress and material deprivation negatively impacts parents' psychological well-being, the relationship between parents, and parenting practices (Conger, Conger, \& Martin, 2010; Duncan, Magnuson, Kalil, \& ZiolGuest, 2012; Gershoff et al., 2007; Yoshikawa, Aber, \& Beardslee, 2012). These changes can

\footnotetext{
${ }^{1}$ Recent evidence suggests that income poverty is an important but insufficient measure of financial hardship for children (Schenck-Fontaine \& Panico, 2019).
} 
then influence the level of engagement that parents have with their child and the types of activities they encourage.

To our knowledge, our paper is the first to describe how children's time use changes when they are exposed to family financial hardship. Related studies have estimated the association between SES such as maternal education and children's time use (Bianchi \& Robinson, 1997; Kalil et al., 2012; Rokicki \& McGovern, 2020), ${ }^{2}$ as well as the association between maternal employment and children's time with parents (e.g. Fox, Han, Ruhm, \& Waldfogel, 2013; Hsin $\&$ Felfe, 2014). However, evidence from longitudinal analyses is limited.

We focus on children's time spent in four key activities: screen time, physical activity, sleep, and reading. These activities were selected due to their associations with children and adolescent's health and developmental outcomes (Hutton, Dudley, Horowitz-Kraus, DeWitt, \& Holland, 2019; Kalb \& van Ours, 2014; Loewen et al., 2019; Mol \& Bus, 2011; Walsh et al., 2018; World Health Organization, 2019). We analyze children's time use using the Longitudinal Study of Australian Children (LSAC), which surveys about 10,000 children and their parents every two years. The LSAC includes a detailed time use diary (TUD) of the children's activities in a 24-hour period when they were aged $0-15$. The LSAC is particularly suited for this study because it has more follow-ups and covers a greater range of ages than any other TUD of children or adolescents.

Using within-child fixed effects models, we estimate how exposure to financial hardship changes children's time use. Our approach recognizes the transient nature of financial hardship (Stevens, 1994) and controls for unobserved fixed confounders (e.g. time-invariant components of parenting style, cognitive ability, and personality). We control for a rich set of timevarying family circumstances, such as parental employment, health and household composition to further isolate the impact of financial hardship on children's time use. We additionally examine whether financial hardship relates to potentially harmful levels of time use, defined as: excessive screen time (top decile by age group), lack of sleep (bottom decile by age), and zero time spent reading and engaged in physical activity on a given day.

\footnotetext{
2 This literature typically finds that children of more highly educated parents or of higher household income engage in more physical activity, read more, study more, and watch TV less than children from lower socioeconomic backgrounds. Other studies (usually of small samples), indicate that children from more disadvantaged families tend to sleep less and have more sleep disturbances (Bøe, Hysing, Stormark, Lundervold, \& Sivertsen, 2012; Buckhalt, El-Sheikh, \& Keller, 2007; Jarrin, McGrath, \& Quon, 2014)
} 
Our main result is that during times of financial hardship, children spend more time using screens and are more likely to spend excessive amounts of time on screens. Also, the probability of excessive screen time increases as the number of financial hardships increases. We show that the increase in screen time is driven by passive screen time (e.g. watching TV), rather than active (e.g. playing video games) or social screen time (e.g. social media use). The results are larger for younger children (aged 2-9 years) than older children (10-15 years), which is potentially concerning from a developmental perspective, given the importance of early childhood investments.

In contrast, we find little evidence that children's time spent reading, sleeping or engaged in physical activity changes when children experience financial hardship. Importantly, our findings hold even when controlling for economic covariates, including household income, which affirms that financial hardship is a state that is distinct from general socioeconomic status.

We also explore possible mechanisms for the increase in screen time, including substitutions away from active time spent with parents, participation in extracurricular activities and out of the home outings, and changes in parent screen time rules. Financial hardship is only associated with the latter: during times of financial hardship, parents are less likely to enforce rules on the amount of time their child watches TV.

\section{Data}

This study uses data from seven waves (2004-2016) of the biennial Longitudinal Study of Australian Children (LSAC). The nationally representative sample consists of approximately 10,000 Australian children from two cohorts: Cohort B and Cohort K. Cohort B follows infants aged $0-1$ years in 2004 ( $n=5,107)$, while Cohort $\mathrm{K}$ follows children aged 4-5 years in 2004 $(n=4,983)$. Data are primarily collected from the main parent (typically the biological mother) through face-to-face interviews, with additional self-completed questionnaires filled out by parents, teachers, child caregivers, and the children themselves at older ages.

An advantage of the LSAC over other comparable longitudinal studies is that it includes time use diaries (TUD). This inclusion allows us to elicit children's time engaged in different activities over a 24-hour period with less recall bias and measurement error than retrospective survey questions (Hofferth, 2006). There are other longitudinal studies with TUDs, but the 
LSAC surveys considerably more children and includes more waves, providing additional statistical power ${ }^{3}$.

Like most longitudinal studies, the LSAC suffers from attrition across waves. Using a child fixed effects regression (see Appendix Table A2), we check for the likely importance of attrition-related bias by estimating the association between child and family characteristics in wave $t$ and the probability of participating in the survey at wave $t+1$. Participation in the following wave was slightly lower when the primary parent was younger or male, lived in a more disadvantaged neighborhood, or when the mother had more psychological distress. Importantly, current financial hardship, our key variable of interest, and other household composition and economic variables (parent's education, employment and income) were unrelated to future survey participation.

\subsection{Financial Hardship}

In each wave of the LSAC, the main parent was asked whether they experienced any of six financial hardship events in the last 12 months due to a shortage of money: (1) could not pay gas, electricity, or telephone bills on time; (2) could not pay the mortgage or rent on time; (3) went without meals; (4) could not heat or cool the home; (5) pawned or sold something; or (6) sought assistance from a welfare or community organization. The six items reflect behaviour changes to cope with the demands of limited financial resources. Further, the items reflect objective aspects of material need and financial hardship rather than a subjective self-assessment of living conditions (Butterworth \& Crosier, 2005). The proportions of observations in our estimation sample for each hardship are shown in Appendix Table A3. Not being able to pay bills on time is the most common, with approximately $13 \%$ of the sample reporting this financial hardship.

Our main financial hardship variable is a binary indicator that equals one when the child's family experienced at least one of the six financial hardships in the last 12 months. $67 \%$ of families experienced no periods of financial hardship, leaving one third of families experiencing financial hardship in at least one wave ${ }^{4}$. Approximately $4.7 \%$ of the sample are in hardship in every wave sampled. Of those families experiencing financial hardship, approximately $38 \%$

\footnotetext{
${ }^{3}$ Other commonly used child TUDs include: the Child Development Supplement from the Panel Study of Income Dynamics which follows children every five years for three waves; the American Time Use Survey which collects a TUD from children aged 15 and older; and the Millennium Cohort Study which includes a TUD in the age-14 sweep.

${ }^{4}$ Proportions of families experiencing financial hardship were $17.91 \%, 8.60 \%, 4.18 \% 2.4 \%$ for one, two, three and four-plus periods, respectively.
} 
report experiencing two or more of the six types of hardships. Transitional probabilities of financial hardship (Appendix Table A4) highlight the transient nature of financial hardship. Of families not experiencing hardship, approximately $8 \%$ move into financial hardship in the following period. If a family is experiencing financial hardship, we find there is an almost 50-50 chance they will continue to experience financial hardship in the following period. ${ }^{5}$

In order to interpret our financial hardship estimates, it is helpful to have an understanding of the key drivers of the variation in financial hardship over time. Existing evidence suggests that there are five broad factors that increase the likelihood of experiencing financial hardship (Bourova, Ramsay, \& Ali, 2019; Heflin, 2016; Heflin \& Butler, 2013; Heflin, Sandberg, \& Rafail, 2009; Sullivan, Turner, \& Danziger, 2008). These are: 1) unforeseen expenses (e.g. car repairs or unexpectedly high utility bills); 2) a lack of income; 3) physical and mental health problems; 4) a lack of employment; and, 5) changes to family composition. Bourova et al. (2019) showed that the most common experience in the lead up to financial difficulties was unforeseen expenses (37\%). This was followed by relying on welfare support (i.e., lack of income) $(33 \%)$ and unexpectedly high utility costs $(27 \%)$.

In Appendix Table A5, we estimate the extent to which the above factors, excluding unforeseen expenses, explain the within-child variation in financial hardship over time. ${ }^{6}$ Consistent with existing studies, we find that financial hardship is associated with household income, parental psychological distress, overall health, single parent status, and parental employment. ${ }^{7}$ However, despite these significant associations, the covariate set explains only $2.3 \%$ of the withinchild variation in financial hardship. In other words, there is substantial unexplained variation in financial hardship over time. Based on the empirical evidence from previous studies, it is likely that a considerable proportion of this unexplained variation is due to unforeseen or unexpectedly high expenses.

\subsection{Time Use Diaries}

Two types of diaries were used to measure time spent engaged on screens (excluding homework time), in physical activity, sleep, and reading: a parent-completed diary (for children 09 years of age) and a child-completed diary (for children aged 10 or older). ${ }^{8}$ For the parent-

\footnotetext{
${ }^{5}$ These values are consistent with previous research that shows experiences of poverty (measured by household income below a poverty threshold) are largely transient (Stevens, 1994).

${ }^{6}$ Information on expenses (unforeseen or otherwise) is unavailable in the LSAC.

${ }^{7}$ Although income is closely related to financial hardship, we find in our data that only $50 \%$ of families experiencing hardship also experience a reduction in household income. Less than 5\% experience employment loss, separation or a decline in physical or mental health.

${ }^{8}$ Examples of the diaries are available in Nguyen et al. (2020a) Appendix Figure C1 and C3.
} 
completed diaries, the child's main parent was asked to complete a TUD the weekday immediately following an interview and one randomly allocated weekend day following an interview. They were asked to record what the child was doing in 15-minute blocks of time, from a given list of activities, starting at 4:00 a.m. on the designated day and finishing at 4:00 a.m. the following day.

From age 10, children completed their own TUD. They recorded what they were doing, the time the activity started, and who they were with. The child was asked to complete the TUD the day before their scheduled interview date. An interviewer electronically recorded the child's TUD during the interview so that any uncertain entries could be clarified. At this age, children completed only one diary. TUDs were collected each wave with the exception of wave 4 (age 6/7) and 5 (age 8/9) for Cohort B, and wave 7 (age 16/17) for Cohort K.

Naturally, the types of activities listed in the TUDs changed as children aged. However, by carefully choosing broad key activities, we measure time spent in each category at each age, which is an important requirement for our within-child fixed effects approach; see Appendix B for each of the specific activities that contributed to the four key time use categories by age and cohort. As the TUDs allowed the child to report multiple activities at once (e.g. watching TV while eating), we included all time spent in the four key activities so that we could capture the total time children engaged in these activities. ${ }^{9}$

Across all waves and cohorts, children in our estimation sample spend on average 2 hours and 39 minutes of non-homework screen time, 1 hour and 55 minutes engaged in physical activity, 32 minutes reading; and 10 hours and 36 minutes sleeping. These four activities, on average, account for approximately 67\% (15.7 hours) of a child's day.

\subsection{Estimation Sample}

We begin with 54,634 time use diary entries from 9,226 children who provide information about financial hardship. Due to developmental differences, we exclude TUDs from the first wave of Cohort B (7,350 observations) as the children were infants and their time use is not comparable to older children. We also remove TUDs that are potentially of poor quality or lacking detail. Specifically, we remove cases when: the parent was "not sure what the child was doing" for more than two hours that day (3,659 entries); the diary had missing data for any time $(1,009)$; the child completed less than 10 different activities that day (437); and, the day

\footnotetext{
${ }^{9}$ This means that the total time engaged in all activities could amount to more than 24 hours. While one could force the total time to be 24 hours by making assumptions about which activity is considered the "primary activity," this would likely result in a loss of information on our key activities for children under ten years of age.
} 
of the week of the time use diary was not reported (28). We also remove diaries that report screen time, physical activity time or reading time more than four standard deviations above the mean time use for their age, and those who report sleep time more than four standard deviations below the mean time use for their age $(1,157)$. Our final estimation sample consists of 8,800 children with 41,449 observations of TUD information across seven waves. ${ }^{10}$

\subsection{Descriptive Analysis of Children's Time Use}

Figure 1 presents mean time use over ages $2-15$, separately by family financial hardship status. Children's screen time increases substantially as they age, growing from less than two hours per day at ages $2 / 3$ to almost four hours per day at ages $14 / 15$. Children experiencing financial hardship have, on average, more screen time than other children, with the gap remaining relatively constant with age. The amount of time children spend engaged in physical activity and reading is relatively constant over ages, while children's average sleep time decreases over time, as expected. Differences by financial hardship are not discernible for mean time spent engaged in physical activity, reading, or sleep.

Kernel densities estimates of the four time use activities by financial hardship are presented in Figure 2. Each time use activity has first been de-meaned by the average time use at each age given the significant trends across ages for screen time and sleep. The estimated density for age de-meaned screen time is noticeably right-shifted for children experiencing financial hardship, implying that these children have a higher average screen time and also have a greater probability of high screen times. Figure 2 also indicates that children in hardship appear to have a higher chance of low or zero reading time and physical activity time.

\section{Fixed Effects Regression Approach}

To estimate how a child's time use changes during periods of family financial hardship, we separately estimate, for each time use activity, regressions with child fixed effects and child age fixed effects. The child fixed effects control for fixed, unobservable characteristics of the child (and their family), while the age fixed effects control for unobserved differences in child and parent behaviours by the child's age, as well as whether the TUD was parent- or childcompleted.

\footnotetext{
${ }^{10}$ Note that our total number of observations includes up to two TUDs per child in the first three waves of data collection
} 
We identify the main coefficients of interest by comparing a child's time use in periods of financial hardship with the same child's time use in periods out of financial hardship. As reported in Section 2, financial hardship is largely transient, with around one third of the sample experiencing financial hardship in some, but not all, waves.

The regression equation for child $i$ in year $t$ can be specified as

$$
\text { time }_{i t}=\beta_{1} \text { finhardship }_{i g t}+\alpha_{i}+\theta_{1} a g e_{i t}^{\prime}+\theta_{2} X_{i t}^{\prime}+u_{i t}
$$

where time $_{i t}$ is amount of time in minutes the child spent in the activity (i.e. screen time, physical activity, reading, or sleep) in year $t$, finhardship $p_{i t}$ is an indicator of whether the child's family experienced financial hardship in the last 12 months, $\alpha_{i}$ is the child fixed-effect, and $a g e_{i t}$ represents the set of age indicators (fixed-effects).

In all specifications, $X_{i t}$ includes time controls (year, month and day of the week the TUD was completed), demographics of the "main" parent (gender, age, Aboriginal or Torres Strait Islander Person, single parent, university education), neighborhood disadvantage, and whether the main parent completed the TUD. ${ }^{11}$ We then sequentially add to $X_{i t}$ variables that are associated with financial hardship (see section 2.1), and that may also impact parenting. Specifically, we include measures of: i) household composition (single parent status, number of other children and adults in the household); ii) parents physical and mental health (using a self-assessed global health score and the Kessler-6 scale); iii) employment (indicators of whether each parent is employed); and, iv) a cubic function of household income. ${ }^{12}$ These variables are added sequentially to show how they influence the financial hardship estimates.

The socioeconomic variables we include capture only a small proportion of the variation in financial hardship, as shown by the low within-child R-squared value in Appendix Table A5. From the literature on financial hardships (see Section 2.1), we expect that in our most complete specification, the financial hardship variable is largely capturing unforeseen or unexpectedly high expenses (such as car repairs or high utility bills). It may also be possible for the variation in financial hardship to include time-concentrated income shocks that are not adequately captured by our income variables, or short-term employment shocks not captured by our

\footnotetext{
11 The main parent is the child's primary caregiver or the parent who knows the child best and who answers the LSAC general survey items. The main parent in most cases (over 90\%) is the child's biological mother. Note that due to the fixed-effect model, the main parent's sex, background and education is likely to be constant across time and drop out of the model, however we have left these variables in the model to capture occasional changes in who is the main parent (for example, through separation).

${ }^{12}$ See Appendix Table A6 for sample means for all control variables, and Appendix C for detailed descriptions of how the neighbourhood, health, employment and income variables are constructed.
} 
employment variable (for example, if a parent lost their job but gained new employment within the two-year survey period). However, given the limited impact that the employment and income covariates have on the financial hardship estimate, we suspect that unobserved timeconcentrated economic shocks are not driving our results.

We also estimate linear probability models with fixed effects to investigate the likelihood of having time use in the "extreme" tails of the time use distributions. We categorize the top 10\% of screen time use by age (indicating excessive screen time), the bottom $10 \%$ of sleep time by age (indicating lack of sleep), and zero minutes per day spent in physical activity and reading as extreme potentially harmful quantities of time use. Exact age-specific cutoffs based on sample deciles for screen time and sleep are shown in Appendix D. Note that while this analysis allows us to investigate whether financial hardship is related to extreme time use on a given day, truly harmful time use would be indicated by a prolonged pattern of extreme time use. ${ }^{13}$

Finally, to further investigate how the relationship between financial hardship and time use differs across the distribution, we estimate fixed effects unconditional quantile regressions (Borgen, 2016; Firpo, Fortin, \& Lemieux, 2009), which we discuss in the following section.

\section{Time Use Regression Results}

\subsection{Main Results}

Table 1 presents estimates of the financial hardship coefficient from child fixed effects regressions. Column (1) shows results when only basic demographic and seasonality controls are included, and suggests that during periods of financial hardship screen time is around 8 minutes higher than in other periods, while sleep, physical activity and reading time are not associated with financial hardship. Columns (2) to (5) show that the estimates are insensitive to the addition of household composition, health, employment and income variables. This implies that it is the experience of financial hardship itself, and not changes to observed socioeconomic circumstances, that appears to be captured by the financial hardship estimate. As mentioned in Section 3 , the variation in financial hardship is most likely to be driven by unforeseen or unexpectedly high expenses.

To put the screen time estimates into more tangible terms, an increase of 8 minutes represents a $5 \%$ increase relative to the average screen time of 159 minutes per day and equates to almost

\footnotetext{
${ }^{13}$ For example, zero physical activity per day over a prolonged period is likely to have a harmful impact on a child's health and well-being.
} 
1 hour a week of additional screen time. ${ }^{14}$ Compared with other covariates in our model (shown in Appendix Table A7), the estimated difference in screen time associated with financial hardship ( 8 minutes) is larger in magnitude than the estimated difference in screen time associated with the child's mother becoming employed ( -4 minutes, $p=.042)$, father becoming employed (4 minutes, $p=.382$ ), and mother and father experiencing good physical health ( -1 minutes, $p$ $=.852$ and -2 minutes, $p=.572$ respectively). The effect of experiencing financial hardship on screen time is also larger in magnitude than a one standard deviation increase in both neighborhood disadvantage ( 3 minutes, $p=.061$ ), and mother and father's psychological distress scores ( 1 minute, $p=.451$ and $p=.504$ respectively). Gaining a younger sibling significantly decreases children's screen time by 11 minutes a day $(p<.001)$, and is the only covariate larger in magnitude than financial hardship.

Column 6 of Table 1 presents coefficient estimates from the fixed effects linear regressions of the extreme and potentially harmful time use outcomes: top decile of screen time, bottom decile of sleep time, and zero minutes of physical activity and reading (see Appendix D for the agespecific cutoffs). The results indicate that during periods of financial hardship, children are approximately 2.0 percentage points more likely to be in the top decile of screen time use for their age. Importantly, the cutoffs we used to construct the top decile screen time variable far exceed the levels of screen time recommended by the World Health Organization (2019) and the Australian Department of Health's 24-hour Movement Guidelines (Australian Government Department of Health, 2019). For example, the Australian Guidelines recommend less than 120 minutes of screen time for children aged five years and older, yet our top decile cutoff at ages four-five is twice as large at 255 minutes. At 488 minutes for ages 14-15, our cutoff is four times the recommended level.

While we do not find significantly higher average physical activity time during periods of financial hardship, we do see a significant increase in the likelihood of children engaging in zero physical activity (by 1.9 percentage points).

Our main results are robust to retaining all TUDs, including potentially low quality or outlier time use records (see Appendix Table A8), and to restricting the sample to children who have experienced at least one period of financial hardship (see Appendix Table A9).

\footnotetext{
${ }^{14}$ While this is not large, if this one hour was instead spent on educational activities with parents, estimates from Fiorini \& Keane (2016, Tables 9 and 10) suggest it could translate to improvements in the child's cognitive skills (by about 0.018 standard deviations) and language skills (by about 0.022 standard deviations).
} 
We also estimate the screen time regression with lags and leads of the financial hardship variable included (see Appendix Table A10). Neither the lag nor lead coefficient is significantly different from zero, and the inclusion of these terms does not markedly change the magnitude or precision of the contemporaneous financial hardship estimate. This result indicates that financial hardship has only a short term association with screen time. That is, once family finances improve, screen time seems to revert back to pre-hardship levels.

\subsection{Severity of financial hardship}

The results in Table 1 are based on our main measure of financial hardship, a binary variable indicating the family experienced at least one of the six listed financial hardships in the past 12 months. This approach was chosen because few families report multiple hardships simultaneously. Nevertheless, we'd expect the associations between financial hardship and time use to be larger in magnitude for families with multiple hardships (i.e. experiencing severe deprivation), and we test this hypothesis by disaggregating our main financial hardship variable into three categories: one reported hardship (10\%); two reported hardships (4.0\%); and, three or more reported hardships (2.0\%). Table 2 presents results from fixed effects regressions using these three variables.

The estimated coefficients show that during periods of three or more financial hardships, relative to periods with no hardships, children spend 15 more minutes on screens per day and are 3.7 percentage points more likely to be spending extreme amounts of time on screens. The latter estimate is over three times larger than the estimate reported for one hardship. Consistent with the results presented in Table 1, one hardship increases the probability of completing zero physical activity, however we don't see an equivalent effect for two or more hardships.

Overall, the results presented in Tables 1 and 2 indicate that children spend more time on screens when their family is experiencing financial hardship than they do in years without financial hardship, particular in years with severe financial hardship. We see less consistent or no significant changes in time spent sleeping, reading or engaged in physical activity. Therefore, in the following subsections we focus additional analyses on screen time.

\subsection{Unconditional Quantile Regressions}

We estimate unconditional quantile regressions with child fixed effects to investigate whether the relationship between financial hardship and screen time changes across the $25^{\text {th }}, 50^{\text {th }}, 75^{\text {th }}$, and $90^{\text {th }}$ percentiles of screen time (Appendix Table A11). The largest point estimate for financial hardship on screen time is at the $50^{\text {th }}$ percentile, with children at this percentile completing 
approximately 11 additional minutes of screen time compared to not being in financial hardship. We also find large coefficient values at the $75^{\text {th }}$ and $90^{\text {th }}$ percentile of screen time (10 and 8 minutes respectively). This analysis indicates that financial hardship impacts children's screen time more at the upper end of the distribution, which is where additional time spent on screens is arguably more harmful (Islam, Biswas, \& Khanam, 2020; Twenge \& Campbell, 2018)

\subsection{Heterogeneity by type of screen time}

Different types of screen time have differential impacts on children's health and development. For example, actively playing video games has been shown to have positive impacts on cognitive development (Suziedelyte, 2015), while passively watching TV is associated with poorer physical and socioemotional outcomes (Kim et al., 2020; Sanders, Parker, del Pozo-Cruz, Noetel, \& Lonsdale, 2019). We therefore examine whether certain types of screen time are more strongly impacted by financial hardship.

We disaggregate our measure of total screen time into three categories: passive screen time (such as watching TV, video or DVD), active screen time (such as playing computer or electronic games, or general computer application use) and social screen time (such as spending time on social media sites, texting, video chat). ${ }^{15}$ We then run fixed-effect regressions using each type of screen time as the outcome. Table 3 shows that passive screen time is approximately eight minutes higher during years of financial hardship, compared to years without any reported hardships. Active and social screen time do not appear to change during periods of financial hardship.

\subsection{Heterogeneity by Day of the Week}

It is possible that financial hardship affects parent and child behaviors differently on weekdays and weekends. For example, the behavioral effects of strained finances and parental stress may be larger on weekends when children have more discretionary time and parents have greater caregiving responsibilities. To test this possibility, we estimate separate fixed effect models for weekend and weekday screen time and present the results in Table $4 .{ }^{16}$ The average change in

\footnotetext{
${ }^{15}$ Social screen time is only captured by the time use diaries for children 10 years old or older (see Appendix B for details).

${ }^{16}$ Parents were asked to complete the TUD for one weekday and one weekend day, while children were asked to complete one TUD for the day before their interview. This resulted in more weekday observations $(24,396)$ than weekend observations $(17,053)$.
} 
screen time when children experience financial hardship is similar across weekdays and weekend days. However, the change in the probability of extreme amounts of screen time is larger and only statistically significant for weekdays (2.0 percentage points). ${ }^{17}$ This result may have human capital implications if, for example, screen time during weekdays is more likely to be substituting away from homework compared with on weekends.

\subsection{Heterogeneity by Child's Age}

It is possible for financial hardship to impact the activities of younger children differently to older children. For example, a younger child's discretionary time may be more controlled and monitored by parents compared to an adolescent. Although we control for age by including age fixed-effects in our models, it is useful to explore whether there is heterogeneity in our financial hardship estimate by age group. In Table 5 we show estimates from fixed effect models for screen time separately for younger children (2-9 years) and older children (10-15 years). These suggest that our main results are driven by younger children. During periods of financial hardship, screen time of younger children is about ten minutes a day higher and is 2.3 percentage points more likely to be at extreme levels. The screen time coefficients for older children are about half the size.

\section{Why Might Screen Time Change During Times of Financial Hardship?}

In this section, we explore potential pathways for our main result. ${ }^{18}$ First, we explore the possibility that the increase in screen time is associated with a substitution away from more costly activities that families in financial hardship are less able to afford or have less discretionary time to spend on. We create a variable for the number of out-of-home activities the child was reported to have attended during the past month from the following: movie theater; sporting event; playground; pool; concert; museum; art gallery; religious service; and, library (available for children aged 4-15 for cohort $\mathrm{K}$, and for children aged 2-13 for cohort B). We also create a variable for the number of extracurricular activities the child was reported to have done with a family member during the last 12 months (available for ages 8-15 for cohort $\mathrm{K}$ and ages 6-13 for Cohort B). The extra-curricular activities include: team or individual sport; art, music, or performance class; and, academic class. As shown in Columns (1) and (2) of Table 6, financial

\footnotetext{
${ }^{17}$ We calculate the top decile separately based on weekend and weekday screen time (see Appendix E). Cut offs for extreme screen time are higher on weekends compared to weekdays.

${ }^{18}$ We utilise survey responses from the LSAC general survey for this section of analysis, and do not restrict the sample to only children with a time use diary. Our specification for these models follows equation 1, but does not include variables directly related to a time use diary (e.g. day of the week).
} 
hardship does not appear to be related to the number of either out-of-home or extracurricular activities.

We next explore the possibility that the increase in screen time is associated with a substitution away from joint parent-child activities, measured with the question: "How much time per week do you spend actively doing things with your children (e.g. playing with them, helping them with personal care, teaching, coaching or actively supervising them, getting them to childcare, school or other activities)?"19 The coefficient estimate in Column 3 of Table 6 suggests that during periods of financial hardship children spend more time with their main parent (by about 9 minutes), but the coefficient is imprecisely estimated and we cannot draw any conclusions.

Finally, we explore whether financial hardship is associated with changes in parental decisionmaking regarding screen time. It is possible that parents experiencing financial hardship have fewer attentional resources to spend on making optimal parenting decisions (Mullainathan \& Shafir, 2013). Parents of children (available for ages 6-15 for cohort K and ages 6-13 for Cohort B) were asked "Are there rules about how many hours [the] child may watch television each week?" In Column (4) of Table 6 we show that during periods of financial hardship, parents are 1.5 percentage points less likely to have rules about TV screen time (significant at only the $10 \%$ level). It is possible that parents in financial hardship are distracted by their pressing financial problems and are less able to enforce rules regarding screen time.

\section{Discussion and Conclusion}

Financial hardship is a highly stressful and difficult situation that can influence children's development above and beyond common measures of socioeconomic disadvantage. In this study we examine how children's time spent in key health and developmental activities changes when their families experience financial hardship. Our empirical approach is to utilize unique panel data on children's time use to estimate within-child fixed effect regressions of children from 2-15 years of age.

We find that during periods of financial hardship, average screen time is 8 minutes per day higher, and the probability of using screens at excessive levels is about 2 percentage points

\footnotetext{
${ }^{19}$ This item is asked of cohort $\mathrm{K}$ when children were 6-15 years, and of cohort B when children were aged 2-13 years. We use survey responses instead of TUDs for this analysis as we are unable to accurately capture parent's active time with the study child from the TUDs. In parent-completed diaries, parent-child time is recorded if they were in the same room or nearby the child if outside. Because young children are often monitored by a main parent, we find a large amount of the child's time is spent with a parent, even, for example, when the child is sleeping, or watching TV.
} 
higher. These results are robust to a number of alternative specifications. We show that while household composition, parental health, employment and income are all associated with spells of financial hardship, the experience of financial hardship is associated with higher screen time conditional on these socioeconomic factors. This is consistent with previous studies (Clark et al., 2021; Schenck-Fontaine \& Panico, 2019) that show financial hardship provides additional information to income in child development models. Given results from past studies, and our own analysis, it is likely that financial hardship is most strongly driven by the inability to meet unforeseen or unexpectedly high expenses. The stress from such situations has been shown to take up considerable cognitive bandwidth and reduce the attentional resources of parents (Mullainathan \& Shafir, 2013).

While 8 additional minutes of screen time per day is a modest amount, the 2 percentage point increase in the probability of being in the top decile of screen time for age is more concerning. The top decile of screen-time equates to three or more hours a day for children aged 2-3 years, and eight or more hours a day for children aged 14-15 years. This is significantly more screen time than is recommended by the Australian Department of Health's 24-hour movement guidelines (Australian Government Department of Health, 2019), which suggest children should spend less than 2 hours a day on screens. According to the World Health Organization (2019), the benefits of reducing screen time include reduced adiposity and improved motor and cognitive development and psychosocial health.

Importantly, we show that our results are driven by passive screen time (e.g. watching TV), and not by active screen time (e.g. playing computer games) or social screen time (e.g. social media or texting). Previous research indicates that while active screen time may have some benefits to cognitive development (Suziedelyte, 2015), passive screen time is associated with poorer mental health, worse health outcomes and lower educations outcomes (Kim et al., 2020; Sanders et al., 2019). We also show that the observed changes in screen time are driven by younger children (aged 2-9 years). Given investments in early childhood are especially valuable for human capital development (Heckman \& Masterov, 2007), these results indicate that financial hardship during younger ages is of particular concern.

Why would experiencing serious financial hardship be associated with an increase in children's time spent on screens? Our exploration of potential pathways does not show evidence to support the hypothesis that the additional screen time is due to reduced investment in extracurricular activities or out of the home activities. We also find no evidence to support the hypothesis that the additional screen time is due to parents investing less time actively engaged 
with their child. However, we do find some evidence suggesting that during periods of financial hardship, parents are less likely to have rules around the quantity of TV children are allowed. Our results imply that one of the challenges that financially stressed parents face could be in establishing and maintaining consistent rules around children's screen time.

Our study is not without limitations. While time use diary data are seen as more reliable than survey questions that ask respondents to estimate their time spent in certain activities (Raley, 2014), the data can be affected by measurement error and reporting bias. We take considerable care in removing diaries that have incomplete information (a sign of low quality) and outliers, and also find our results are robust to including these diaries. By examining four activities in isolation, we do not analyze how a change in time spent in one activity impacts time spent in another. Recent research has employed compositional data analysis techniques to conduct analysis on time use in a 24-hour period to address this issue (Dumuid et al., 2018). However, as the first three waves of our data included reports of multiple concurrent activities, we could not restrict the data to 24 hours of time and follow this approach without making (strong) assumptions about the primary activity of the child and potentially losing information on the key activities of interest. Notably, we can rule out displacement effects on sleep, reading and physical activity time, as our results suggest that these time uses are no higher or lower during periods of hardship.

Overall, our findings highlight that children increase their time spent using screens during periods of financial hardship. These findings may help explain why financially disadvantaged children have worse health, cognitive, and behavioral outcomes. By recognizing the specific changes in children's time use during periods of financial hardship, programs can be developed to better support parents and families during difficult times. 


\section{References}

Adelantado-Renau, M., Moliner-Urdiales, D., Cavero-Redondo, I., Beltran-Valls, M. R., Martínez-Vizcaíno, V., \& Álvarez-Bueno, C. (2019). Association Between Screen Media Use and Academic Performance Among Children and Adolescents: A Systematic Review and Meta-analysis. JAMA Pediatrics. doi:10.1001/jamapediatrics.2019.3176

Australian Government Department of Health. (2019). Australia's physical activity and sedentary behaviour guidelines. Retrieved from https://www1.health.gov.au/internet/main/publishing.nsf/content/healthpubhlth-strateg-phys-act-guidelines

Bianchi, S. M., \& Robinson, J. (1997). What Did You Do Today? Children's Use of Time, Family Composition, and the Acquisition of Social Capital. Journal of Marriage and Family, 59(2), 332-344. doi:10.2307/353474

Bøe, T., Hysing, M., Stormark, K. M., Lundervold, A. J., \& Sivertsen, B. (2012). Sleep problems as a mediator of the association between parental education levels, perceived family economy and poor mental health in children. Journal of

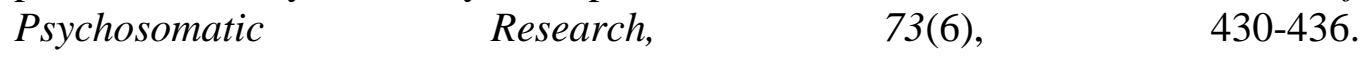
doi:https://doi.org/10.1016/j.jpsychores.2012.09.008

Borga, L. G. (2019). Children's Own Time Use and its Effect on Skill Formation. The Journal of Development Studies, 55(5), 876-893. doi:10.1080/00220388.2018.1499893

Borgen, N. T. (2016). Fixed effects in unconditional quantile regression. The Stata Journal, $16(2), 403-415$.

Bourova, E., Ramsay, I., \& Ali, P. (2019). The Experience of Financial Hardship in Australia: Causes, Impacts and Coping Strategies. Journal of Consumer Policy, 42(2), 189221. doi:10.1007/s10603-018-9392-1

Buckhalt, J. A., El-Sheikh, M., \& Keller, P. (2007). Children's sleep and cognitive functioning: race and socioeconomic status as moderators of effects. Child Development, 78(1), 213-231.

Butterworth, P., \& Crosier, T. (2005). Deriving a measure of financial hardship from the HILDA survey. Australian Social Policy (2005), 1-12.

Caetano, G., Kinsler, J., \& Teng, H. (2019). Towards causal estimates of children's time allocation on skill development. Journal of Applied Econometrics, 34(4), 588605. doi:10.1002/jae.2700

Cappuccio, F. P., Taggart, F. M., Kandala, N.-B., Currie, A., Peile, E., Stranges, S., \& Miller, M. A. (2008). Meta-analysis of short sleep duration and obesity in children and adults. Sleep, 31(5), 619-626.

Cawley, J., \& Liu, F. (2012). Maternal employment and childhood obesity: A search for mechanisms in time use data. Economics \& Human Biology, 10(4), 352-364.

Clark, A. E., D'Ambrosio, C., \& Barazzetta, M. (2021). Childhood circumstances and young adulthood outcomes: The role of mothers' financial problems. Health Economics, 30(2), 342-357. doi:https://doi.org/10.1002/hec.4194

Cobb-Clark, D. A., Salamanca, N., \& Zhu, A. (2019). Parenting style as an investment in human development. Journal of Population Economics, 32(4), 1315-1352. doi:10.1007/s00148-018-0703-2

Conger, R. D., Conger, K. J., \& Martin, M. J. (2010). Socioeconomic Status, Family Processes, and Individual Development. Journal of Marriage and Family, 72(3), 685-704. doi:10.1111/j.1741-3737.2010.00725.x 
Del Boca, D., Monfardini, C., \& Nicoletti, C. (2017). Parental and Child Time Investments and the Cognitive Development of Adolescents. Journal of Labor Economics, 35(2), 565-608.

Dumuid, D., Stanford, T. E., Martin-Fernández, J.-A., Pedišić, Ž., Maher, C. A., Lewis, L. K., ... Olds, T. (2018). Compositional data analysis for physical activity, sedentary time and sleep research. Statistical Methods in Medical Research, 27(12), 37263738. doi:10.1177/0962280217710835

Duncan, G. J., Magnuson, K., Kalil, A., \& Ziol-Guest, K. (2012). The Importance of Early Childhood Poverty. Social Indicators Research, 108(1), 87-98. doi:10.1007/s11205-011-9867-9

Fertig, A., Glomm, G., \& Tchernis, R. (2009). The connection between maternal employment and childhood obesity: inspecting the mechanisms. Review of Economics of the Household, 7(3), 227. doi:10.1007/s11150-009-9052-y

Fiorini, M., \& Keane, M. P. (2014). How the Allocation of Children's Time Affects Cognitive and Noncognitive Development. Journal of Labor Economics, 32(4), 787-836. doi:10.1086/677232

Firpo, S., Fortin, N. M., \& Lemieux, T. (2009). Unconditional Quantile Regressions. Econometrica, 77(3), 953-973. doi:10.3982/ecta6822

Fox, L., Han, W.-J., Ruhm, C., \& Waldfogel, J. (2013). Time for Children: Trends in the Employment Patterns of Parents, 1967-2009. Demography, 50(1), 25-49. doi:10.1007/s13524-012-0138-4

Gershoff, E. T., Aber, J. L., Raver, C. C., \& Lennon, M. C. (2007). Income is not enough: Incorporating material hardship into models of income associations with parenting and child development. Child Development, 78(1), 70-95.

Guryan, J., Hurst, E., \& Kearney, M. (2008). Parental Education and Parental Time with Children. Journal of Economic Perspectives, 22(3), 23-46. doi:doi: 10.1257/jep.22.3.23

Haveman, R., \& Wolfe, B. (1995). The Determinants of Children's Attainments: A Review of Methods and Findings. Journal of economic literature, 33(4), 1829-1878.

Heckman, J. J., \& Masterov, D. V. (2007). The productivity argument for investing in young children. Applied Economic Perspectives and Policy, 29(3), 446-493.

Heflin, C. H. (2016). Family Instability and Material Hardship: Results from the 2008 Survey of Income and Program Participation. Journal of Family and Economic Issues, 37(3), 359-372. doi:10.1007/s10834-016-9503-6

Heflin, C. H., \& Butler, J. S. (2013). Why Do Women Enter and Exit From Material Hardship? Journal of Family Issues, 34(5), 631-660. doi:10.1177/0192513x12442822

Heflin, C. H., Sandberg, J., \& Rafail, P. (2009). The structure of material hardship in US households: An examination of the coherence behind common measures of wellbeing. Social problems, 56(4), 746-764.

Hofferth, S. L. (2006). Response Bias In A Popular Indicator Of Reading To Children. Sociological Methodology, 36(1), 301-315. doi:doi:10.1111/j.14679531.2006.00182.x

Hsin, A., \& Felfe, C. (2014). When Does Time Matter? Maternal Employment, Children's Time With Parents, and Child Development. Demography, 51(5), 1867-1894. doi:10.1007/s13524-014-0334-5

Hutton, J. S., Dudley, J., Horowitz-Kraus, T., DeWitt, T., \& Holland, S. K. (2019). Associations between screen-based media use and brain white matter integrity in preschool-aged children. JAMA Pediatrics, e193869-e193869. 
Iceland, J., \& Bauman, K. J. (2007). Income poverty and material hardship: How strong is the association? The Journal of Socio-Economics, 36(3), 376-396. doi:https://doi.org/10.1016/j.socec.2006.12.003

Islam, M. I., Biswas, R. K., \& Khanam, R. (2020). Effect of internet use and electronic gameplay on academic performance of Australian children. Scientific Reports, 10(1), 21727. doi:10.1038/s41598-020-78916-9

Jarrin, D. C., McGrath, J. J., \& Quon, E. C. (2014). Objective and subjective socioeconomic gradients exist for sleep in children and adolescents. Health Psychology, 33(3), 301.

Kalb, G., \& van Ours, J. C. (2014). Reading to young children: A head-start in life? Economics of Education Review, 40, 1-24. doi:https://doi.org/10.1016/j.econedurev.2014.01.002

Kalil, A., Ryan, R., \& Corey, M. (2012). Diverging Destinies: Maternal Education and the Developmental Gradient in Time With Children. Demography, 49(4), 1361-1383. doi: 10.1007/s13524-012-0129-5

Kessler, R. C., Andrews, G., Colpe, L. J., Hiripi, E., Mroczek, D. K., Normand, S. L. T., . . . Zaslavsky, A. M. (2002). Short screening scales to monitor population prevalences and trends in non-specific psychological distress. Psychological Medicine, 32(6), 959-976. doi:10.1017/S0033291702006074

Kim, S., Favotto, L., Halladay, J., Wang, L., Boyle, M. H., \& Georgiades, K. (2020). Differential associations between passive and active forms of screen time and adolescent mood and anxiety disorders. Social Psychiatry and Psychiatric Epidemiology, 55(11), 1469-1478. doi:10.1007/s00127-020-01833-9

LeBlanc, A. G., Katzmarzyk, P. T., Barreira, T. V., Broyles, S. T., Chaput, J.-P., Church, T. S., ... Kuriyan, R. (2015). Correlates of total sedentary time and screen time in 911 year-old children around the world: the international study of childhood obesity, lifestyle and the environment. PLOS ONE, 10(6), e0129622.

Loewen, O. K., Maximova, K., Ekwaru, J. P., Faught, E. L., Asbridge, M., Ohinmaa, A., \& Veugelers, P. J. (2019). Lifestyle behavior and mental health in early adolescence. Pediatrics, 143(5), e20183307.

Mani, A., Mullainathan, S., Shafir, E., \& Zhao, J. (2013). Poverty Impedes Cognitive Function. Science, 341(6149), 976-980. doi:10.1126/science.1238041

McCulloch, A., \& Joshi, H. E. (2002). Child development and family resources: Evidence from the second generation of the 1958 British birth cohort. Journal of Population Economics, 15(2), 283-304. doi:10.1007/s001480100067

Mol, S. E., \& Bus, A. G. (2011). To read or not to read: a meta-analysis of print exposure from infancy to early adulthood. Psychological bulletin, 137(2), 267.

Mullainathan, S., \& Shafir, E. (2013). Scarcity: Why having too little means so much: Macmillan.

Nguyen, H. T., Connelly, L. B., Le, H. T., Mitrou, F., Taylor, C. L., \& Zubrick, S. R. (2020). Ethnicity differentials in academic achievements: the role of time investments. Journal of Population Economics, 33(4), 1381-1418. doi:10.1007/s00148-02000774-6

Price, J., \& Kalil, A. (2019). The Effect of Mother-Child Reading Time on Children's Reading Skills: Evidence From Natural Within-Family Variation. Child Development, 90(6), e688-e702. doi:https://doi.org/10.1111/cdev.13137

Raley, S. (2014). Time Use, Inequality, and Child Well-Being. In A. Ben-Arieh, F. Casas, I. Frønes, \& J. E. Korbin (Eds.), Handbook of Child Well-Being: Theories, Methods and Policies in Global Perspective (pp. 999-1031). Dordrecht: Springer Netherlands. 
Rokicki, S., \& McGovern, M. E. (2020). Heterogeneity in Early Life Investments: A Longitudinal Analysis of Children's Time Use. Review of Income and Wealth, 66(3), 647-676. doi:https://doi.org/10.1111/roiw.12440

Sanders, T., Parker, P. D., del Pozo-Cruz, B., Noetel, M., \& Lonsdale, C. (2019). Type of screen time moderates effects on outcomes in 4013 children: evidence from the Longitudinal Study of Australian Children. International Journal of Behavioral Nutrition and Physical Activity, 16(1), 117. doi:10.1186/s12966-019-0881-7

Schenck-Fontaine, A., \& Panico, L. (2019). Many Kinds of Poverty: Three Dimensions of Economic Hardship, Their Combinations, and Children's Behavior Problems. Demography, 56(6), 2279-2305. doi:10.1007/s13524-019-00833-y

Shah, A. K., Mullainathan, S., \& Shafir, E. (2012). Some consequences of having too little. Science, 338(6107), 682-685.

Short, K. S. (2005). Material and Financial Hardship and Income-Based Poverty Measures in the USA. Journal of Social Policy, 34(1), 21-38. doi:10.1017/S0047279404008244

Stevens, A. H. (1994). The Dynamics of Poverty Spells: Updating Bane and Ellwood. The American Economic Review, 84(2), 34-37. Retrieved from http://www.jstor.org/stable/2117797

Subrahmanyam, K., Kraut, R. E., Greenfield, P. M., \& Gross, E. F. (2000). The impact of home computer use on children's activities and development. Future of Children, 10(2), 123-144. doi:Doi 10.2307/1602692

Sullivan, J. X., Turner, L., \& Danziger, S. (2008). The relationship between income and material hardship. Journal of Policy Analysis and Management, 27(1), 63-81. doi:https://doi.org/10.1002/pam.20307

Suziedelyte, A. (2015). Media and human capital development: Can video game playing make you smarter? Economic inquiry, 53(2), 1140-1155.

Twenge, J. M., \& Campbell, W. K. (2018). Associations between screen time and lower psychological well-being among children and adolescents: Evidence from a population-based study. Preventive Medicine Reports, 12, 271-283. doi:https://doi.org/10.1016/j.pmedr.2018.10.003

Walsh, J. J., Barnes, J. D., Cameron, J. D., Goldfield, G. S., Chaput, J. P., Gunnell, K. E., . . . Tremblay, M. S. (2018). Associations between 24 hour movement behaviours and global cognition in US children: a cross-sectional observational study. Lancet Child Adolesc Health, 2(11), 783-791. doi:10.1016/s2352-4642(18)30278-5

World Health Organization. (2019). Guidelines on physical activity, sedentary behaviour and sleep for children under 5 years of age (9241550538). Retrieved from https://apps.who.int/iris/bitstream/handle/10665/311664/9789241550536eng.pdf

Yoshikawa, H., Aber, J. L., \& Beardslee, W. R. (2012). The effects of poverty on the mental, emotional, and behavioral health of children and youth: implications for prevention. Am Psychol, 67(4), 272-284. doi:10.1037/a0028015

Zilanawala, A., \& Pilkauskas, N. V. (2012). Material hardship and child socioemotional behaviors: Differences by types of hardship, timing, and duration. Children and Youth Services Review, 34(4), 814-825. 


\section{Tables}

Table 1: Fixed-Effects Estimates of Children's Time Use During Periods of Financial Hardship

\begin{tabular}{|c|c|c|c|c|c|c|}
\hline & \multicolumn{5}{|c|}{ Time use (Minutes) } & \multirow{2}{*}{$\begin{array}{c}\text { Extreme } \\
\text { levels of } \\
\text { time use } \\
\text { (binary) } \\
(6)\end{array}$} \\
\hline & (1) & (2) & (3) & (4) & (5) & \\
\hline $\begin{array}{l}\text { Screen Time } \\
\text { Financial hardship }\end{array}$ & $\begin{array}{l}8.437 * * * \\
(2.541)\end{array}$ & $\begin{array}{l}7.850 * * * \\
(2.541)\end{array}$ & $\begin{array}{l}7.632 * * * \\
(2.546)\end{array}$ & $\begin{array}{l}7.601 * * * \\
(2.542)\end{array}$ & $\begin{array}{l}7.711 * * * \\
(2.544)\end{array}$ & $\begin{array}{c}0.020 * * * \\
(0.007)\end{array}$ \\
\hline $\begin{array}{l}\text { Sleep Time } \\
\text { Financial hardship }\end{array}$ & $\begin{array}{c}0.049 \\
(1.909)\end{array}$ & $\begin{array}{c}0.248 \\
(1.914)\end{array}$ & $\begin{array}{c}0.521 \\
(1.918)\end{array}$ & $\begin{array}{c}0.586 \\
(1.917)\end{array}$ & $\begin{array}{c}0.511 \\
(1.919)\end{array}$ & $\begin{array}{l}-0.001 \\
(0.007)\end{array}$ \\
\hline $\begin{array}{l}\text { Physical Activity Time } \\
\text { Financial hardship }\end{array}$ & $\begin{array}{l}-1.600 \\
(2.075)\end{array}$ & $\begin{array}{l}-1.669 \\
(2.077)\end{array}$ & $\begin{array}{l}-1.542 \\
(2.082)\end{array}$ & $\begin{array}{l}-1.610 \\
(2.083)\end{array}$ & $\begin{array}{l}-1.707 \\
(2.086)\end{array}$ & $\begin{array}{c}0.019 * * \\
(0.009)\end{array}$ \\
\hline $\begin{array}{l}\text { Reading Time } \\
\text { Financial hardship }\end{array}$ & $\begin{array}{l}-0.577 \\
(0.839)\end{array}$ & $\begin{array}{l}-0.443 \\
(0.842)\end{array}$ & $\begin{array}{l}-0.412 \\
(0.847)\end{array}$ & $\begin{array}{l}-0.451 \\
(0.848)\end{array}$ & $\begin{array}{l}-0.498 \\
(0.849)\end{array}$ & $\begin{array}{l}-0.001 \\
(0.009)\end{array}$ \\
\hline $\begin{array}{l}\text { Covariates included: } \\
\text { Demographic \& Diary } \\
\text { Household Composition } \\
\text { Parents' Health } \\
\text { Parents' Employment } \\
\text { Household Income }\end{array}$ & $\begin{array}{l}\text { YES } \\
\text { NO } \\
\text { NO } \\
\text { NO } \\
\text { NO }\end{array}$ & $\begin{array}{l}\text { YES } \\
\text { YES } \\
\text { NO } \\
\text { NO } \\
\text { NO }\end{array}$ & $\begin{array}{l}\text { YES } \\
\text { YES } \\
\text { YES } \\
\text { NO } \\
\text { NO }\end{array}$ & $\begin{array}{l}\text { YES } \\
\text { YES } \\
\text { YES } \\
\text { YES } \\
\text { NO }\end{array}$ & $\begin{array}{l}\text { YES } \\
\text { YES } \\
\text { YES } \\
\text { YES } \\
\text { YES }\end{array}$ & $\begin{array}{l}\text { YES } \\
\text { YES } \\
\text { YES } \\
\text { YES } \\
\text { YES }\end{array}$ \\
\hline $\begin{array}{l}\text { Notes: } N=8800 \text { children wit } \\
\text { regression results. Column ( } 1 \\
\text { (2) adds household composi } \\
\text { status); column ( } 3 \text { ) adds pare } \\
\text { adds a cubic function of hous } \\
\text { results with extreme time us } \\
\text { decile of screen time users b } \\
\text { treme time refers to zero min } \\
* * p<0.05 ; * p<0.10\end{array}$ & $\begin{array}{l}449 \text { time } \\
\text { ludes con } \\
\text { (i.e. num } \\
\text { mental ar } \\
\text { d income } \\
\text { a binary o } \\
\text { e respecti } \\
\text { Clustere }\end{array}$ & $\begin{array}{l}\text { diary obser } \\
\text { for child a } \\
\text { of children } \\
\text { nysical hea } \\
\text { lumn }(6) \mathrm{sl} \\
\text { me. Scree } \\
\text { (see Appe }\end{array}$ & $\begin{array}{l}\text { tions. Colt } \\
\text { family bac } \\
\text { nd adults } \\
\text {; column } \\
\text { Ns within } \\
\text { nd Sleep } \\
\text { ix D for c }\end{array}$ & $\begin{array}{l}\text { s }(1-5) \text { sho } \\
\text { ound and di } \\
\text { he househo } \\
\text { adds parent } \\
\text { d fixed-effe } \\
\text { eme time u } \\
\text { ffs). Physic }\end{array}$ & $\begin{array}{l}\text { ws within ch } \\
\text { lary charact } \\
\text { ld, includin } \\
\text { employm } \\
\text { ct linear pr } \\
\text { se refers to } \\
\text { al activity }\end{array}$ & $\begin{array}{l}\text { xed-effect } \\
\text { es; column } \\
\text { gle parent } \\
\text { column (5) } \\
\text { lity model } \\
\text { nd bottom } \\
\text { eading ex- } \\
* * p<0.01 \text {; }\end{array}$ \\
\hline
\end{tabular}


Table 2: Fixed-Effects Estimates of Children's Time Use During Periods of Financial Hardship: By Severity of Financial Hardship

\begin{tabular}{|c|c|c|c|c|}
\hline \multirow{2}{*}{ Screen Time } & \multicolumn{2}{|c|}{$\begin{array}{c}\text { Time use } \\
\text { (Minutes) } \\
(1)\end{array}$} & \multicolumn{2}{|c|}{$\begin{array}{l}\text { Extreme levels } \\
\text { of time use } \\
\text { (binary) } \\
\text { (2) }\end{array}$} \\
\hline & & & & \\
\hline 1 hardship & $7.300 * * *$ & $(2.772)$ & $0.012^{*}$ & $(0.007)$ \\
\hline 2 hardships & 6.398 & (4.324) & $0.035^{* * *}$ & $(0.012)$ \\
\hline $3+$ hardships & $15.03 * *$ & (6.614) & $0.037 * *$ & $(0.018)$ \\
\hline \multicolumn{5}{|l|}{ Sleep Time } \\
\hline 1 hardship & 0.352 & (2.109) & 0.005 & $(0.008)$ \\
\hline 2 hardships & 1.737 & (3.116) & -0.013 & $(0.011)$ \\
\hline 3+ hardships & -1.369 & (5.313) & -0.009 & $(0.017)$ \\
\hline \multicolumn{5}{|c|}{ Physical Activity Time } \\
\hline 1 hardship & -2.999 & (2.319) & $0.022 * *$ & $(0.009)$ \\
\hline 2 hardships & 2.508 & (3.435) & 0.013 & $(0.014)$ \\
\hline $3+$ hardships & -1.380 & $(5.062)$ & 0.002 & $(0.021)$ \\
\hline \multicolumn{5}{|l|}{ Reading Time } \\
\hline 1 hardship & -0.771 & $(0.907)$ & -0.001 & $(0.010)$ \\
\hline 2 hardships & 0.832 & $(1.475)$ & -0.006 & $(0.016)$ \\
\hline $3+$ hardships & -1.629 & $(2.302)$ & 0.012 & $(0.022)$ \\
\hline \multicolumn{5}{|c|}{$\begin{array}{l}\text { Notes: Total number of observations equals } 41,449 \text {, with } 34,751 \text { zero hardship observations, } 4,178 \\
1 \text { hardship observations }(10.0 \%), 1,6732 \text { hardship observations }(4.0 \%) \text {, and } 8473+\text { hardship ob- } \\
\text { servations }(2.0 \%) \text {. Regression specifications correspond to the fixed-effects regressions shown in } \\
\text { Table } 1 \text { (column } 5 \text { and column } 6 \text { ), see the Table } 1 \text { note for more details. Clustered standard errors } \\
\text { shown in parentheses, } *^{* *} p<0.01 ; * * p<0.05 ; * \text { p }<0.10\end{array}$} \\
\hline
\end{tabular}

Table 3: Fixed-Effects Estimates of Children's Screen Time During Periods of Financial Hardship: By Type of Screen Time

\begin{tabular}{lccc}
\hline & $\begin{array}{c}\text { Passive } \\
(1)\end{array}$ & $\begin{array}{c}\text { Active } \\
(2)\end{array}$ & $\begin{array}{c}\text { Social } \\
(3)\end{array}$ \\
\hline Financial hardship & $8.534 * * *$ & -0.523 & -0.078 \\
& $(2.135)$ & $(1.575)$ & $(2.068)$ \\
Number of Observations & & & \\
Number of Children & 41,449 & 41,449 & 16,154 \\
\hline
\end{tabular}

Notes: Passive screen time includes watching TV, Video or DVD. Active screen time includes playing computer games or electronic games (e.g. Xbox) or general computer application use (e.g. Microsoft Word). Social screen time includes spending time on social media sites, texting, video chat, online chat. Number of observations varies due to social screen time not captured by time use diaries in all waves of data collection - see Appendix B. Regression specifications correspond to the fixed-effects regressions shown in Table 1 (column 5), see the Table 1 note for more details. Clustered standard errors in parentheses, *** $\mathrm{p}<0.01 ; * * \mathrm{p}<0.05 ; * \mathrm{p}<0.10$ 
Table 4: Fixed-Effects Estimates of Children's Screen Time During Periods of Financial Hardship: By Day of the Week

\begin{tabular}{lllll}
\hline & \multicolumn{2}{c}{ Weekday Day } & \multicolumn{2}{c}{ Weekend Day } \\
\hline & $\begin{array}{l}\text { Minutes of } \\
\text { screen time }\end{array}$ & Top decile & $\begin{array}{l}\text { Minutes of } \\
\text { screen time }\end{array}$ & Top decile \\
\hline Financial hardship & $\begin{array}{l}8.788^{* * *} \\
(3.295)\end{array}$ & $0.020^{* *}$ & $9.003^{* *}$ & 0.012 \\
& & $(0.009)$ & $(3.990)$ & $(0.011)$ \\
Number of Observations & 24,396 & 24,396 & 17,053 & 17,053 \\
Number of Children & 8,500 & 8,500 & 7,779 & 7,779 \\
\hline
\end{tabular}

Notes: Weekday (weekend) day refers to children's time use on a weekday (weekend). Regression specifications correspond to the fixed-effects regressions shown in Table 1 (column 5 and column 6). See the Table 1 note for more details. Clustered standard errors in parentheses, $* * * \mathrm{p}<0.01 ; * * \mathrm{p}<0.05 ; * \mathrm{p}<0.10$

Table 5: Fixed-Effects Estimates of Children's Screen Time During Periods of Financial Hardship: By Child's Age

\begin{tabular}{|c|c|c|c|c|}
\hline & \multicolumn{2}{|c|}{ Younger children (2-9 years) } & \multicolumn{2}{|c|}{ Older children ( $10-15$ years) } \\
\hline & $\begin{array}{l}\text { Minutes of } \\
\text { time }\end{array}$ & Top decile & $\begin{array}{l}\text { Minutes of } \\
\text { time }\end{array}$ & Top decile \\
\hline Financial hardship & $\begin{array}{l}9.761 * * * \\
(3.080)\end{array}$ & $\begin{array}{l}0.023^{* *} \\
(0.010)\end{array}$ & $\begin{array}{l}5.206 \\
(5.639)\end{array}$ & $\begin{array}{l}0.008 \\
(0.013)\end{array}$ \\
\hline Number of Observations & 25,295 & 25,295 & 16,154 & 16,154 \\
\hline Number of Children & 7,741 & 7,741 & 7,759 & 7,759 \\
\hline
\end{tabular}

Notes: Regression specifications correspond to the fixed-effects regressions shown in Table 1 (column 5 and column 6). See the Table 1 note for more details. Clustered standard errors in parentheses, ${ }^{* * *} \mathrm{p}<0.01 ; * * \mathrm{p}<0.05$; $* \mathrm{p}<0.10$

Table 6: Fixed-Effects Estimates of Potential Channels of Financial Hardship

\begin{tabular}{lcccc}
\hline & $\begin{array}{c}\text { Out of Home } \\
\text { Activities } \\
\text { (Number) }\end{array}$ & $\begin{array}{c}\text { Extra-curricu- } \\
\text { lar Activities } \\
\text { (Number) }\end{array}$ & $\begin{array}{c}\text { Main Parent } \\
\text { Active Time } \\
\text { with Child } \\
\text { (Minutes) }\end{array}$ & $\begin{array}{c}\text { Rules Around } \\
\text { Television } \\
\text { (Binary) }\end{array}$ \\
\hline Financial hardship & $(1)$ & $(2)$ & $(3)$ & $(4)$ \\
Number of Observations & 0.019 & -0.008 & 9.425 & $-0.015^{*}$ \\
Number of Children & $(0.017)$ & $(0.019)$ & $(23.216)$ & $(0.009)$ \\
\hline Nit & 48,958 & 30,685 & 32,035 & 35,071 \\
\hline
\end{tabular}

Notes: Column (1) shows fixed effect regression for number of out of home activities child has done with a family member in the last month, column (2) shows fixed effect regression for number of extra-curricular activities child has participated in the last 12 months, column (3) shows fixed effect regression for parent reported average weekly active time with child (main parent), Column (4) shows fixed effect linear probability model for whether the there are rules (=1) around how many hours of television the child watches per week. Models includes controls for child and family background, year and month of interview, parent's mental and physical health, parent's employment, income and age fixed effects. Number of observations changes due to item not asked all in waves of data collection. Clustered standard errors in parentheses, $* * * \mathrm{p}<0.01 ; * * \mathrm{p}<0.05 ; * \mathrm{p}<0.10$ 


\section{Figures}

Figure 1: Mean Time Use Across Ages Separately by Financial Hardship Status
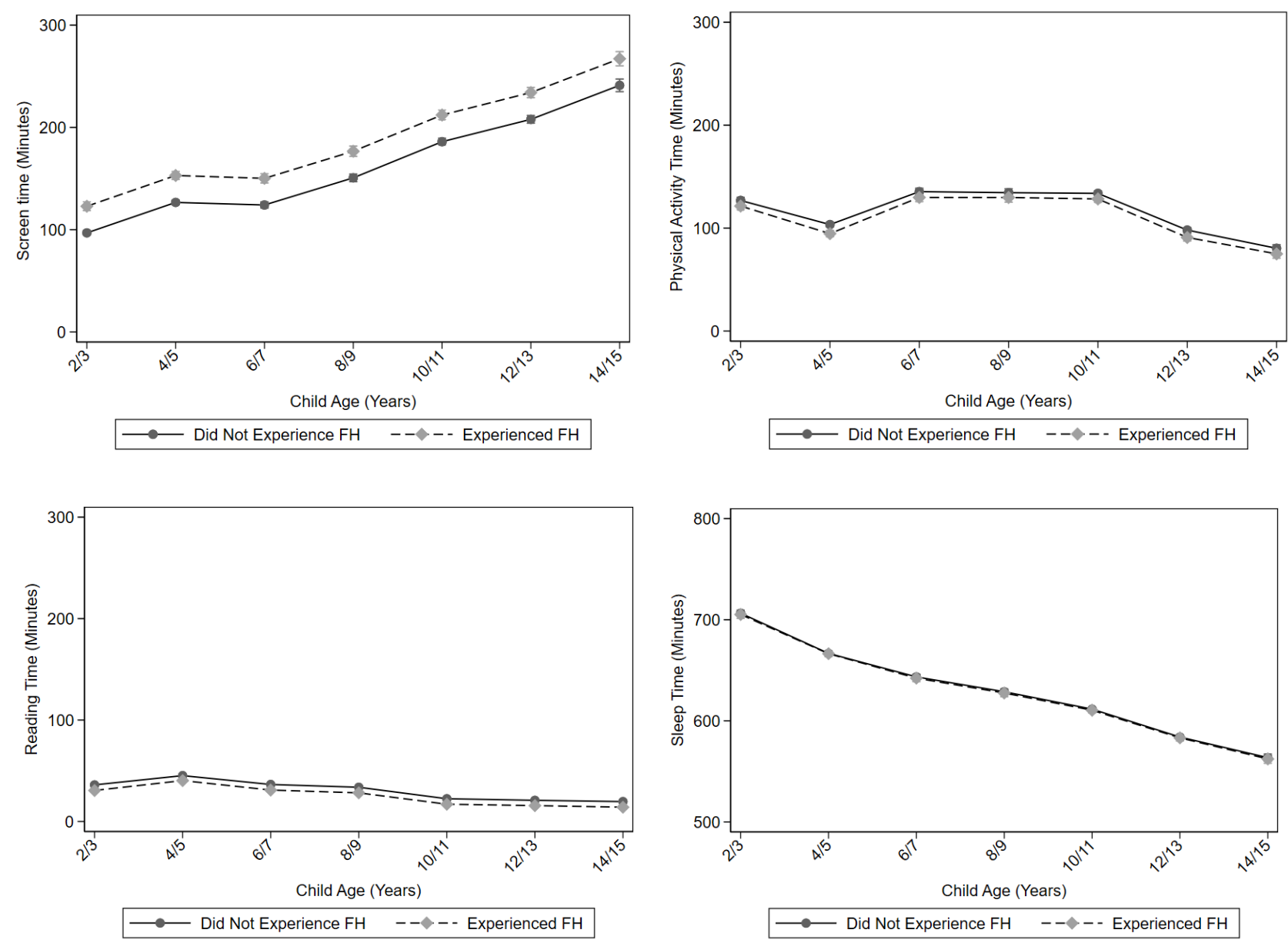
Figure 2: Kernel Density Estimates of the Age De-Meaned Time Use Distributions Separately by Financial Hardship Status
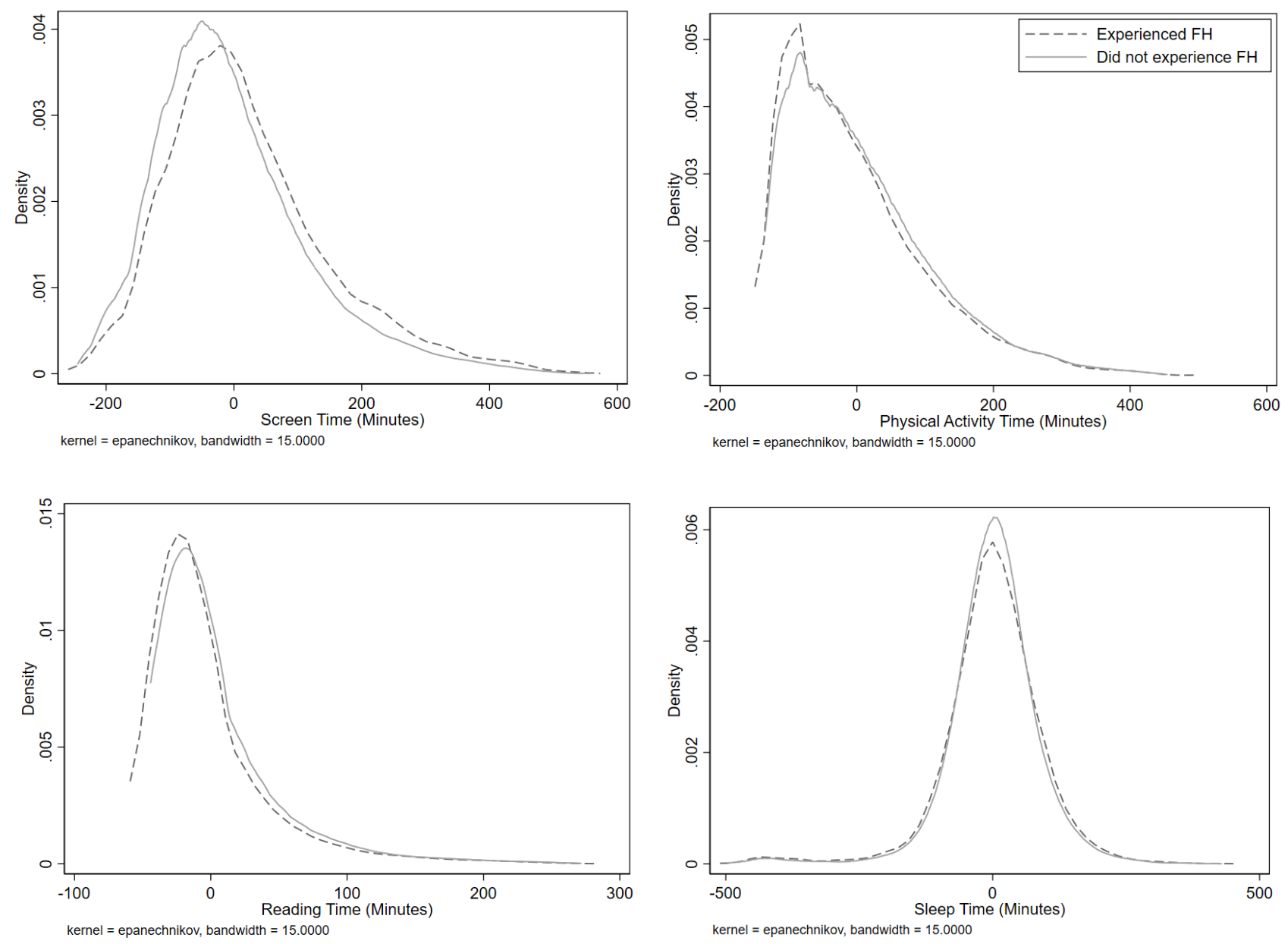


\section{Appendix A - Supplementary tables}

Table A1: Mean Child Outcomes for Children Experiencing Disadvantage by Different Measures of Disadvantage

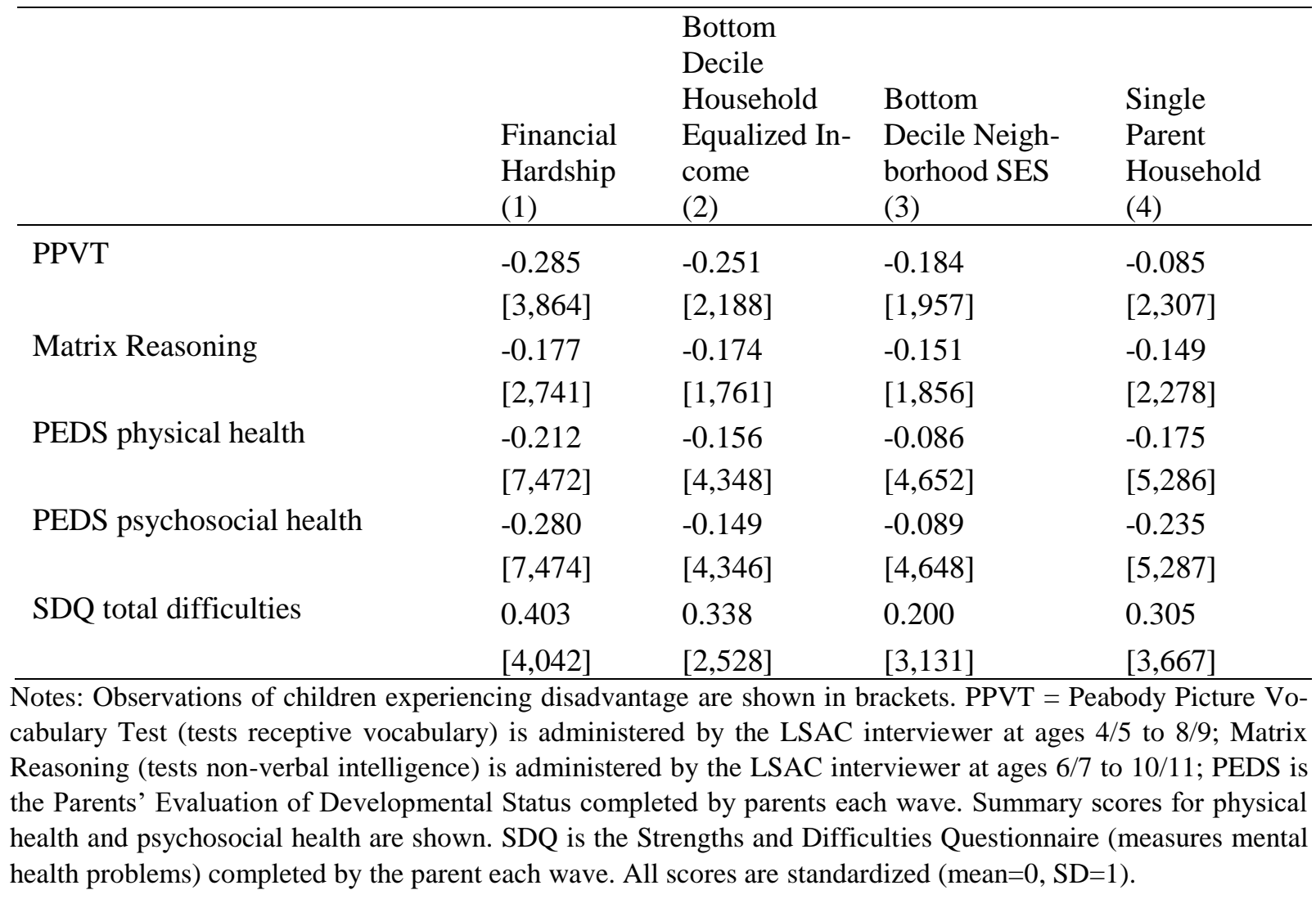


Table A2: Fixed-Effects Estimates of Participating in Next Wave's Survey

\begin{tabular}{lll}
\hline & \multicolumn{2}{l}{ Participation in Next } \\
& \multicolumn{2}{l}{ Wave's Survey } \\
\hline Financial hardship & 0.005 & $(0.004)$ \\
Number of older siblings & 0.006 & $(0.005)$ \\
Number of younger siblings & -0.002 & $(0.004)$ \\
Number of same aged siblings & 0.124 & $(0.081)$ \\
Number of other people in household & 0.004 & $(0.004)$ \\
Main parent is female & $0.028^{* *}$ & $(0.013)$ \\
Main parent's age & $0.002^{* *}$ & $(0.001)$ \\
Main parent Aboriginal or Torres Strait Islander Person & 0.002 & $(0.034)$ \\
Main parent has a university degree & 0.002 & $(0.009)$ \\
Single Parent & 0.034 & $(0.035)$ \\
Neighborhood disadvantage & $-0.016^{* * *}$ & $(0.004)$ \\
Mother psychological distress & $-0.002^{* * * *}$ & $(0.001)$ \\
Father psychological distress & -0.001 & $(0.001)$ \\
Mother poor global health & 0.004 & $(0.006)$ \\
Father poor global health & 0.003 & $(0.006)$ \\
Mother employed & -0.005 & $(0.004)$ \\
Father employed & -0.005 & $(0.009)$ \\
Household weekly income $(/ 10,000)$ & $0.051^{*}$ & $(0.027)$ \\
Household weekly income $(/ 10,000)$ squared & -0.005 & $(0.020)$ \\
Household weekly income $(/ 10,000)$ cubed & 0.001 & $(0.003)$ \\
& & \\
Number of unique observations & 50,419 & \\
Number of children & 10,075 & \\
\hline Non The o & &
\end{tabular}

Notes: The outcome variable is whether the study child participates in the next wave of data collection $(=1)$, before data cleaning. The model includes a child-specific fixed effect and age-at-interview fixed effect. Health, employment and income variables are described in Appendix C. Clustered standard errors in parentheses. $* * * \mathrm{p}<0.01 ; * * \mathrm{p}<0.05$; * $\mathrm{p}<0.10$. 
Table A3: Proportions of Sample Experiencing Types of Financial Hardship

\begin{tabular}{lc}
\hline Over the last 12 months, due to a shortage of money, have any of the following happened? & $\%$ \\
\hline a) You have not been able to pay gas, electricity or telephone bills on time? & 13.09 \\
b) You could not pay the mortgage or rent on time? & 5.00 \\
c) Adults or children have gone without meals? & 1.11 \\
d) You have been unable to heat or cool your home? & 1.24 \\
e) You have pawned or sold something? & 2.52 \\
f) You have sought assistance from a welfare or community organisation? & 2.34 \\
Total Experienced Financial Hardship & 16.16 \\
\hline
\end{tabular}

Note: $N=41,449$ observations from 8800 children

Table A4: Transitional Probabilities of Experiencing Financial Hardship

Financial Hardship at $t+1$

Did not experience fi- Experienced financial nancial hardship hardship

\begin{tabular}{lccc}
\hline & $\begin{array}{c}\text { Did not experience fi- } \\
\text { nancial hardship } \\
\text { Experienced financial } \\
\text { hardship }\end{array}$ & $92.24 \%$ & $7.76 \%$ \\
\hline
\end{tabular}


Table A5: Fixed-Effect Estimates of Correlates of Financial Hardship

\begin{tabular}{lcc}
\hline & \multicolumn{2}{c}{ Financial Hardship } \\
\hline Number of older siblings & $0.016^{*}$ & $(0.009)$ \\
Number of younger siblings & 0.004 & $(0.007)$ \\
Number of same aged siblings & -0.239 & $(0.163)$ \\
Number of other people in household & -0.011 & $(0.007)$ \\
Main parent is female & -0.005 & $(0.023)$ \\
Main parent's age & $-0.003^{* * *}$ & $(0.001)$ \\
Main parent Aboriginal or Torres Strait Islander Person & 0.147 & $(0.227)$ \\
Main parent has a university degree & 0.005 & $(0.016)$ \\
Single Parent & $0.174^{* * *}$ & $(0.046)$ \\
Neighborhood disadvantage & -0.003 & $(0.007)$ \\
Mother psychological distress & $0.009^{* * *}$ & $(0.001)$ \\
Father psychological distress & $0.004^{* * *}$ & $(0.001)$ \\
Mother poor global health & 0.017 & $(0.011)$ \\
Father poor global health & $0.023^{* *}$ & $(0.011)$ \\
Mother employed & $-0.025^{* * *}$ & $(0.007)$ \\
Father employed & $-0.031^{*}$ & $(0.016)$ \\
Household weekly income (/10,000) & $-0.192^{* * *}$ & $(0.033)$ \\
Household weekly income (/10,000) squared & $0.090^{* * *}$ & $(0.018)$ \\
Household weekly income (/10,000) cubed & $-0.008^{* * *}$ & $(0.002)$ \\
& & \\
\hline Number of unique observations & 41,449 & \\
Number of children & 8,800 & \\
R-Square (within) & 0.023 & \\
\hline No Oun & & \\
\hline
\end{tabular}

Notes: Outcome is whether child experiences financial hardship. Health, employment and income variables are described in Appendix C. Model also includes child's age fixed effects and indicators for missing observations in covariates. Clustered standard errors presented in parentheses. $* * * \mathrm{p}<0.01 ; * * \mathrm{p}<0.05$; * $\mathrm{p}<0.10$. 
Appendix Table A6: Sample Means of Key Regression Covariates

\begin{tabular}{lcc}
\hline & Sample Mean & $\begin{array}{c}\text { Standard De- } \\
\text { viation }\end{array}$ \\
\hline Financial hardship & 0.162 & 0.368 \\
Number of older siblings & 0.797 & 0.481 \\
Number of younger siblings & 0.659 & 0.895 \\
Number of same aged siblings & 0.031 & 0.792 \\
Number of other people in household & 0.105 & 0.183 \\
Main parent is female & 0.966 & 0.181 \\
Main parent's age & 38.999 & 6.364 \\
Main parent Aboriginal or Torres Strait Islander Person & 0.014 & 0.118 \\
Main parent has a university degree & 0.363 & 0.181 \\
Single Parent & 0.115 & 0.320 \\
Neighborhood disadvantage & -0.165 & 0.612 \\
Mother psychological distress & 9.068 & 3.297 \\
Father psychological distress & 8.673 & 2.745 \\
Mother poor global health & 0.077 & 0.266 \\
Father poor global health & 0.070 & 0.254 \\
Mother employed & 0.716 & 0.451 \\
Father employed & 0.955 & 0.208 \\
Household weekly income ( /10,000) & 0.234 & 0.183 \\
Household weekly income ( /10,000) squared & 0.088 & 0.539 \\
Household weekly income ( /10,000) cubed & 0.083 & 4.069 \\
Mother completed time use diary & 0.563 & 0.496 \\
& & \\
\hline Number of unique observations & 41,449 & \\
Number of children & 8,800 & \\
\hline Note: Health, employment and income variables are described in Appendix C. & \\
& & \\
\hline
\end{tabular}


Table A7: Fixed-Effects Estimates of Children's Time Use

\begin{tabular}{|c|c|c|c|c|c|c|}
\hline \multirow[b]{2}{*}{ Financial hardship } & \multirow{2}{*}{\multicolumn{2}{|c|}{ Screen Time (Mir }} & \multicolumn{2}{|c|}{$\begin{array}{l}\text { Top decile of screen } \\
\text { time (Binary) } \\
\text { (2) }\end{array}$} & \multicolumn{2}{|c|}{$\begin{array}{c}\text { Zero physical activity } \\
\text { time (Binary) } \\
\text { (3) }\end{array}$} \\
\hline & & & $0.020 * * *$ & $(0.007)$ & $0.019 * *$ & $(0.009)$ \\
\hline Number of older siblings & 1.208 & $(2.867)$ & 0.007 & $(0.007)$ & 0.002 & $(0.009)$ \\
\hline Number of younger siblings & $-11.084 * * *$ & (2.190) & $-0.014 * *$ & $(0.005)$ & $-0.021 * * *$ & $(0.007)$ \\
\hline Number of same aged siblings & -27.601 & (39.797) & $0.047 * *$ & $(0.022)$ & 0.172 & $(0.157)$ \\
\hline Number of other people in household & 2.493 & (2.478) & 0.001 & $(0.006)$ & -0.007 & $(0.008)$ \\
\hline Main parent is female & $-13.520 *$ & $(7.891)$ & 0.009 & $(0.019)$ & -0.003 & $(0.024)$ \\
\hline Main parent's age & 0.019 & $(0.804)$ & -0.001 & $(0.002)$ & -0.002 & $(0.003)$ \\
\hline $\begin{array}{l}\text { Main parent Aboriginal or Torres } \\
\text { Strait Islander Person }\end{array}$ & -9.643 & $(52.450)$ & 0.067 & $(0.139)$ & -0.073 & $(0.167)$ \\
\hline Main parent has a university degree & $-9.386^{*}$ & $(5.036)$ & -0.008 & $(0.011)$ & 0.005 & $(0.015)$ \\
\hline Single Parent & -14.607 & $(17.019)$ & -0.024 & $(0.040)$ & $-0.156 * * *$ & $(0.057)$ \\
\hline Neighborhood disadvantage & $4.439 *$ & $(2.372)$ & -0.004 & $(0.006)$ & -0.007 & $(0.008)$ \\
\hline Mother psychological distress & 0.245 & $(0.326)$ & 0.001 & $(0.001)$ & 0.001 & $(0.001)$ \\
\hline Father psychological distress & 0.217 & $(0.324)$ & 0.000 & $(0.001)$ & $0.002 *$ & $(0.001)$ \\
\hline Mother poor global health & -0.650 & (3.494) & $-0.019 * *$ & $(0.009)$ & $0.028 * *$ & $(0.011)$ \\
\hline Father poor global health & -1.835 & (3.249) & -0.009 & $(0.008)$ & -0.010 & $(0.011)$ \\
\hline Mother employed & $-4.418 * *$ & (2.177) & $-0.014 * * *$ & $(0.006)$ & $0.016 * *$ & $(0.007)$ \\
\hline Father employed & 4.160 & (4.758) & -0.002 & $(0.012)$ & 0.010 & $(0.015)$ \\
\hline Household income $(/ 10,000)$ & 11.534 & $(12.088)$ & $0.060 * *$ & $(0.027)$ & 0.048 & $(0.038)$ \\
\hline Household income $(/ 10,000)$ squared & -10.237 & $(6.583)$ & -0.015 & $(0.013)$ & -0.014 & $(0.019)$ \\
\hline Household income $(/ 10,000)$ cubed & $1.277 * *$ & $(0.617)$ & 0.001 & $(0.001)$ & 0.001 & $(0.002)$ \\
\hline Mother completed Time Use Diary & $0.001 * *$ & $(0.001)$ & 0.003 & $(0.011)$ & 0.006 & $(0.011)$ \\
\hline Diary completed in February & $-51.549 * * *$ & $(16.629)$ & -0.083 & $(0.156)$ & -0.074 & $(0.064)$ \\
\hline Diary completed in March & $-35.840 * *$ & $(17.284)$ & -0.040 & $(0.047)$ & 0.007 & $(0.070)$ \\
\hline Diary completed in April & -20.670 & $(16.520)$ & -0.009 & $(0.045)$ & 0.033 & $(0.068)$ \\
\hline Diary completed in May & $-50.779 * * *$ & $(16.454)$ & -0.056 & $(0.044)$ & 0.029 & $(0.068)$ \\
\hline Diary completed in June & $-30.997 *$ & $(16.440)$ & -0.031 & $(0.045)$ & 0.052 & $(0.068)$ \\
\hline Diary completed in July & -11.169 & $(16.418)$ & 0.001 & $(0.044)$ & 0.063 & $(0.068)$ \\
\hline Diary completed in August & $-44.743 * * *$ & $(16.378)$ & -0.055 & $(0.044)$ & 0.038 & $(0.068)$ \\
\hline Diary completed in September & -24.127 & $(16.517)$ & -0.016 & $(0.045)$ & 0.032 & $(0.068)$ \\
\hline Diary completed in October & -25.006 & $(16.663)$ & -0.022 & $(0.045)$ & 0.030 & $(0.068)$ \\
\hline Diary completed in November & $-56.514 * * *$ & $(16.729)$ & -0.062 & $(0.045)$ & 0.023 & $(0.068)$ \\
\hline Diary completed in December & -20.018 & $(17.652)$ & -0.015 & $(0.047)$ & 0.028 & $(0.070)$ \\
\hline Diary completed on a Tuesday & $-5.122 * *$ & $(2.566)$ & -0.009 & $(0.006)$ & $-0.024 * * *$ & $(0.009)$ \\
\hline Diary completed on a Wednesday & $-5.804 * *$ & (2.518) & $-0.013 * *$ & $(0.006)$ & $-0.023 * * *$ & $(0.009)$ \\
\hline Diary completed on a Thursday & $-10.508 * * *$ & $(2.563)$ & $-0.010^{*}$ & $(0.006)$ & -0.012 & $(0.009)$ \\
\hline Diary completed on a Friday & $8.007 * * *$ & (2.548) & -0.011 & $(0.006)$ & -0.013 & $(0.009)$ \\
\hline Diary completed on a Saturday & $38.893 * * *$ & (2.228) & $0.051 * * *$ & $(0.006)$ & $-0.074 * * *$ & $(0.008)$ \\
\hline Diary completed on a Sunday & $32.473 * * *$ & (2.144) & $0.024 * * *$ & $(0.006)$ & $-0.044 * * *$ & $(0.007)$ \\
\hline Nur & 41,449 & & 41,449 & & 41,449 & \\
\hline Number of children & 8,800 & & 8,800 & & 8,800 & \\
\hline
\end{tabular}

Notes: Regressions correspond to those displayed in Table 1 (column 5 and column 6). Year fixed effects, age fixed effect and indicators for missing observations not shown. Standard errors clustered at the child-diary type level are presented in parentheses. $* * * \mathrm{p}<0.01 ; * * \mathrm{p}<0.05 ; * \mathrm{p}<0.10$. 
Table A8: Fixed-Effects Estimates of Children's Screen Time During Periods of Financial Hardship: Inclusion of All Diaries

\begin{tabular}{|c|c|c|}
\hline & $\begin{array}{c}\text { Screen Time(Minutes) } \\
(1) \\
\end{array}$ & $\begin{array}{l}\text { Top decile of screen time } \\
\text { (Binary) } \\
\text { (2) }\end{array}$ \\
\hline Financial hardship & $\begin{array}{c}7.062 * * * \\
(2.438)\end{array}$ & $\begin{array}{c}0.017 * * * \\
(0.006)\end{array}$ \\
\hline Number of Observations & 47,251 & 47,251 \\
\hline Number of Children & 8,869 & 8,869 \\
\hline
\end{tabular}

Table A9: Fixed-Effects Estimates of Children's Screen Time During Periods of Financial Hardship: Restricted Sample

Screen Time (Minutes) Extreme levels of time use (binary)

\begin{tabular}{lcc}
\hline Screen Time & & \\
Financial hardship & $8.637 * * *$ & $0.020 * * *$ \\
& $(2.628)$ & $(0.007)$ \\
& 13,543 & 13,543 \\
Number of Observations & 2,911 & 2,911 \\
Number of Children &
\end{tabular}

Notes: Sample has been restricted to children that experienced at least one period of financial hardship. Models correspond to those shown in Table 1 (column 5 and column 6). See the Table 1 note for more details. Clustered standard errors in parentheses, $* * * \mathrm{p}<0.01 ; * * \mathrm{p}<0.05 ; * \mathrm{p}<0.10$ 
Table A10: Fixed-Effects Estimates of Children's Screen Time with Lag and Lead Effects

\begin{tabular}{|c|c|c|c|}
\hline & $\begin{array}{c}\text { Time use } \\
\text { (Minutes) } \\
\text { Lag } \\
\text { (1) }\end{array}$ & $\begin{array}{l}\text { Time use } \\
\text { (Minutes) } \\
\text { Lead } \\
(2)\end{array}$ & $\begin{array}{c}\text { Time use } \\
\text { (Minutes) } \\
\text { Lag and Lead } \\
\text { (3) }\end{array}$ \\
\hline \multicolumn{4}{|l|}{ Screen Time } \\
\hline Financial hardship & $\begin{array}{c}6.384 * * \\
(3.093)\end{array}$ & $\begin{array}{c}8.213 * * * \\
(2.770)\end{array}$ & $\begin{array}{c}7.879 * * \\
(3.486)\end{array}$ \\
\hline Financial Hardship Lagged & $\begin{array}{l}-1.049 \\
(2.729)\end{array}$ & - & $\begin{array}{l}-4.243 \\
(3.037)\end{array}$ \\
\hline Financial Hardship Lead & $\begin{array}{l}- \\
-\end{array}$ & $\begin{array}{l}-2.222 \\
(2.878)\end{array}$ & $\begin{array}{l}-3.942 \\
(3.357)\end{array}$ \\
\hline Number of Observations & 34,909 & 36,163 & 29,561 \\
\hline Number of Children & 8,412 & 8,180 & 7,781 \\
\hline
\end{tabular}

Table A11: Fixed-Effects Unconditional Quantile Estimates of Children's Screen Time During Periods of Financial Hardship

\begin{tabular}{lcccc}
\hline & $25^{\text {th }}$ & $50^{\text {th }}$ & $75^{\text {th }}$ & $90^{\text {th }}$ \\
\hline Financial hardship & $5.934^{* * *}$ & $11.068^{* * *}$ & $10.008^{*}$ & 8.032 \\
& $(2.085)$ & $(3.101)$ & $(5.285)$ & $(9.536)$
\end{tabular}

Notes: $N=8800$ children with 41,449 time use diary observations. Coefficient estimates are given for unconditional quantile regressions at the $25^{\text {th }}, 50^{\text {th }}, 75^{\text {th }}$ and $90^{\text {th }}$ percentile of screen time. $10^{\text {th }}$ percentile not shown as this corresponded to zero screen time. Models includes controls for child and family background and diary characteristics, household composition, parent's mental and physical health, parent's employment and household income. Clustered robust standard errors in parentheses. $* * * \mathrm{p}<0.01 ; * * \mathrm{p}<0.05 ; * \mathrm{p}<0.10$ 


\section{Appendix B -Items Contributing to Time Use Categories}

\begin{tabular}{|c|c|c|c|c|c|c|c|c|c|c|c|c|}
\hline & & & Par & nt Con & leted D & ary & & & Chil & Complete & iary & \\
\hline Category & Items & $0-1 \mathrm{~B}$ & $2-3 \mathrm{~B}$ & $4-5 \mathrm{~B}$ & $4-5 \mathrm{~K}$ & $6-7 \mathrm{~K}$ & $8-9 \mathrm{~K}$ & 10-11B & $\begin{array}{c}10- \\
11 \mathrm{~K}\end{array}$ & $12-13 B$ & $\begin{array}{c}12- \\
13 \mathrm{~K}\end{array}$ & $\begin{array}{r}14- \\
15 \mathrm{~K}\end{array}$ \\
\hline \multirow{16}{*}{ 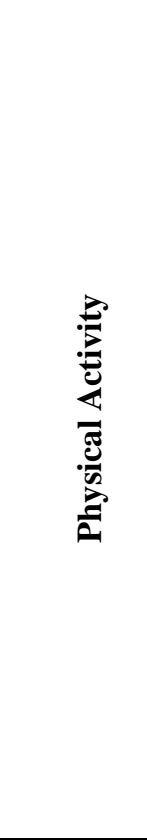 } & Crawl, climb, swing arms or legs & $\mathrm{x}$ & - & - & - & - & - & - & - & - & - & - \\
\hline & Active free play (e.g running, climbing, ball game) & - & $\mathrm{x}$ & $\mathrm{x}$ & - & $\mathrm{x}$ & $\mathrm{x}$ & - & - & - & - & - \\
\hline & Walking (for travel or fun) & - & $\mathrm{x}$ & $\mathrm{x}$ & $\mathrm{x}$ & $\mathrm{x}$ & $\mathrm{x}$ & - & - & - & - & - \\
\hline & Ride bicycle, trike etc. (for travel or fun) & - & $\mathrm{x}$ & $\mathrm{x}$ & $\mathrm{x}$ & $\mathrm{x}$ & $\mathrm{x}$ & - & - & - & - & - \\
\hline & Other exercise - swim / dance/ run about & - & - & - & $\mathrm{x}$ & - & - & - & - & - & - & - \\
\hline & Organised sport/physical activity (e.g. swim, dance, Auskick) & - & - & - & - & $\mathrm{x}$ & $\mathrm{x}$ & - & - & - & - & - \\
\hline & Active activities & - & - & - & - & - & - & - & $\mathrm{x}$ & - & - & - \\
\hline & Organised team sports and training & - & - & - & - & - & - & $\mathrm{x}$ & $\mathrm{x}$ & $\mathrm{x}$ & $\mathrm{x}$ & $\mathrm{x}$ \\
\hline & Organised individual sport i.e. swimming & - & - & - & - & - & - & $\mathrm{x}$ & $\mathrm{x}$ & $\mathrm{x}$ & $\mathrm{x}$ & $\mathrm{x}$ \\
\hline & Ball games, riding a bike, scooter, skateboard & - & - & - & - & - & - & - & $\mathrm{x}$ & - & - & - \\
\hline & Taking pet for a walk & - & - & - & - & - & - & - & $\mathrm{x}$ & - & - & - \\
\hline & Walking pets / playing with pets & - & - & - & - & - & - & $\mathrm{x}$ & - & $\mathrm{x}$ & $\mathrm{x}$ & $\mathrm{x}$ \\
\hline & Unstructured active play & - & - & - & - & - & - & $\mathrm{x}$ & - & $\mathrm{x}$ & $\mathrm{x}$ & $\mathrm{x}$ \\
\hline & Active club activities & - & - & - & - & - & - & $\mathrm{x}$ & - & $\mathrm{x}$ & $\mathrm{x}$ & $\mathrm{x}$ \\
\hline & (Travel) By foot & - & - & - & - & - & - & $\mathrm{x}$ & $\mathrm{x}$ & $\mathrm{x}$ & $\mathrm{x}$ & $\mathrm{x}$ \\
\hline & (Travel) By bike, scooter, skateboard etc. & - & - & - & - & - & - & $\mathrm{x}$ & $\mathrm{x}$ & $\mathrm{x}$ & $\mathrm{x}$ & $\mathrm{x}$ \\
\hline \multirow{4}{*}{$\frac{2}{\bar{d}}$} & Sleeping, napping & $\mathrm{x}$ & $\mathrm{x}$ & $\mathrm{x}$ & $\mathrm{x}$ & $\mathrm{x}$ & $\mathrm{x}$ & - & - & - & - & - \\
\hline & Napping (not night-time sleep) & - & - & - & - & - & - & $\mathrm{x}$ & $\mathrm{x}$ & $\mathrm{x}$ & $\mathrm{x}$ & $\mathrm{x}$ \\
\hline & Difference between reported bed time and wake up time & - & - & - & - & - & - & - & $\mathrm{x}$ & - & - & - \\
\hline & Difference between reported sleep time and wake up time & - & - & - & - & - & - & $\mathrm{x}$ & - & $\mathrm{x}$ & $\mathrm{x}$ & $\mathrm{x}$ \\
\hline \multirow{4}{*}{ 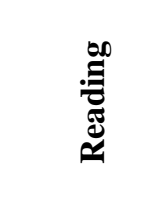 } & Read a story, talked/sung to, sing/talk & $\mathrm{x}$ & $\mathrm{x}$ & $\mathrm{x}$ & $\mathrm{x}$ & $\mathrm{x}$ & - & - & - & - & - & - \\
\hline & Being read or told a story & - & - & - & - & - & $\mathrm{x}$ & - & - & - & - & - \\
\hline & Reading or looking at book by self & - & - & - & - & $\mathrm{x}$ & $\mathrm{x}$ & - & - & - & - & - \\
\hline & Reading or being read to for leisure & - & - & - & - & - & - & $\mathrm{x}$ & $\mathrm{x}$ & $\mathrm{x}$ & $\mathrm{x}$ & $\mathrm{x}$ \\
\hline
\end{tabular}




\begin{tabular}{|c|c|c|c|c|c|c|c|c|c|c|c|c|}
\hline \multirow{18}{*}{ 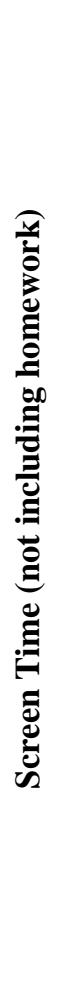 } & Watching TV, a video, or a DVD (P) & $\mathrm{x}$ & $\mathrm{x}$ & $\mathrm{x}$ & $\mathrm{x}$ & $\mathrm{x}$ & $\mathrm{x}$ & $\mathrm{x}$ & $\mathrm{x}$ & $\mathrm{x}$ & $\mathrm{x}$ & $\mathrm{x}$ \\
\hline & Using computer/computer game (A) & - & $\mathrm{x}$ & $\mathrm{x}$ & $\mathrm{x}$ & $\mathrm{x}$ & $\mathrm{x}$ & - & - & - & - & - \\
\hline & Electronic media, games, computer use (A) & - & - & - & - & - & - & - & $\mathrm{x}$ & - & - & - \\
\hline & Playing Games (electronic device) (A) & - & - & - & - & - & - & $\mathrm{x}$ & - & $\mathrm{x}$ & $\mathrm{x}$ & $\mathrm{x}$ \\
\hline & Computer games internet (A) & - & - & - & - & - & - & - & $\mathrm{x}$ & - & - & - \\
\hline & Computer game - not internet (A) & - & - & - & - & - & - & - & $\mathrm{x}$ & - & - & - \\
\hline & Xbox, PlayStation, Nintendo, Wii (A) & - & - & - & - & - & - & - & $\mathrm{x}$ & - & - & - \\
\hline & Downloading/posting media (S) & - & - & - & - & - & - & $\mathrm{x}$ & - & $\mathrm{x}$ & $\mathrm{x}$ & $\mathrm{x}$ \\
\hline & Internet shopping (S) & - & - & - & - & - & - & $\mathrm{x}$ & - & $\mathrm{x}$ & $\mathrm{x}$ & $\mathrm{x}$ \\
\hline & General Internet Browsing $(\mathrm{S})$ & - & - & - & - & - & - & $\mathrm{x}$ & - & $\mathrm{x}$ & $\mathrm{x}$ & $\mathrm{x}$ \\
\hline & Creating/maintaining websites (S) & - & - & - & - & - & - & $\mathrm{x}$ & - & $\mathrm{x}$ & $\mathrm{x}$ & $\mathrm{x}$ \\
\hline & General application use (e.g. Microsoft Office) (A) & - & - & - & - & - & - & $\mathrm{x}$ & - & $\mathrm{x}$ & $\mathrm{x}$ & $\mathrm{x}$ \\
\hline & Spending time on social networking sites (S) & - & - & - & - & - & - & $\mathrm{x}$ & - & $\mathrm{x}$ & $\mathrm{x}$ & $\mathrm{x}$ \\
\hline & Texting, email, social networking such as Facebook or Twitter (S) & - & - & - & - & - & - & - & $\mathrm{x}$ & - & - & - \\
\hline & Skype or Webcam (S) & - & - & - & - & - & - & $\mathrm{x}$ & $\mathrm{x}$ & $\mathrm{x}$ & $\mathrm{x}$ & $\mathrm{x}$ \\
\hline & Texting/email (S) & - & - & - & - & - & - & $\mathrm{x}$ & - & $\mathrm{x}$ & $\mathrm{x}$ & $\mathrm{x}$ \\
\hline & Online chatting/instant messaging (S) & - & - & - & - & - & - & $\mathrm{x}$ & - & $\mathrm{x}$ & $\mathrm{x}$ & $\mathrm{x}$ \\
\hline & Other Internet/electronic device use (S) & - & - & - & - & - & - & $\mathrm{x}$ & $\mathrm{x}$ & $\mathrm{x}$ & $\mathrm{x}$ & $\underline{x}$ \\
\hline
\end{tabular}

Note: $\mathrm{B} / \mathrm{K}$ refers to items asked to the age group specified in the corresponding cohort of children, (P) refers to Passive screen time, (A) refers to Active screen time and (S) refers to Social screen time. 


\section{Appendix C - Description of regression covariates}

Included in our health controls is parent's mental and physical health. Mental health of both parents is measured using the Kessler-6 (K6) scale (Kessler et al., 2002), a six-item scale measuring psychological distress. This scale consists of six items related to distress including whether the parent felt nervous; hopeless; restless or fidgety; worthless; so depressed that nothing could cheer them up and/or that everything was an effort, in the last four weeks. Total scores range from 6 to 30 with higher scores reflecting a greater level of psychological distress.

We create an indicator for poor physical health, if the parents responds to the item "In general, would you say your own health is...?" with poor or fair.

Using self-reported employment status, we include a dummy variable for whether the child's mother and father are employed.

We create a household income variable by combining self-reported imputed gross weekly income of both parents (where applicable). Income was inflated to 2017-2018 Australian dollar values using consumer price index (CPI) data from the Australian Bureau of Statistics (ABS) and divided by 10,000 .

Our measure of neighborhood disadvantage uses the Socio-Economic Index for Areas (SEIFA) Index of Relative Socio-Economic Disadvantage score of the child's local area, provided by the Australian Bureau of Statistics Census of Population and Housing data 2006 and 2011. We standardize and reverse this scale for ease of interpretation, such that higher scores indicate more disadvantaged neighborhoods. 
Appendix D: Cut-offs for Extreme Levels of Time Use

\begin{tabular}{|c|c|c|c|}
\hline & All & Weekday & Weekend \\
\hline Age & \multicolumn{3}{|c|}{ Screen Time - Top Decile } \\
\hline $2 / 3$ & 195 & 210 & 195 \\
\hline $4 / 5$ & 255 & 255 & 270 \\
\hline $6 / 7$ & 255 & 210 & 285 \\
\hline $8 / 9$ & 315 & 255 & 330 \\
\hline $10 / 11$ & 395 & 373 & 455 \\
\hline $12 / 13$ & 425 & 401 & 487 \\
\hline $14 / 15$ & 488 & 474 & 535 \\
\hline Age & \multicolumn{3}{|c|}{ Sleep - Bottom Decile } \\
\hline $2 / 3$ & 600 & 600 & 615 \\
\hline $4 / 5$ & 585 & 600 & 585 \\
\hline $6 / 7$ & 570 & 570 & 570 \\
\hline $8 / 9$ & 540 & 555 & 540 \\
\hline $10 / 11$ & 530 & 530 & 532 \\
\hline $12 / 13$ & 490 & 485 & 515 \\
\hline $14 / 15$ & 455 & 450 & 490 \\
\hline Observations & 41,499 & 24,396 & 17,053 \\
\hline
\end{tabular}

